\title{
Inhibition of quorum sensing in Pseudomonas aeruginosa biofilm bacteria by a halogenated furanone compound
}

\author{
Morten Hentzer, ${ }^{1}$ Kathrin Riedel, ${ }^{2}$ Thomas B. Rasmussen, ${ }^{1}$ \\ Arne Heydorn, ${ }^{1}$ Jens Bo Andersen, ${ }^{1}$ Matthew R. Parsek, ${ }^{3}$ \\ Scott A. Rice, ${ }^{4}$ Leo Eberl, ${ }^{2}$ Søren Molin, ${ }^{1}$ Niels Høiby, ${ }^{5}$ Staffan Kjelleberg ${ }^{4}$ \\ and Michael Givskov ${ }^{1}$
}

Author for correspondence: Michael Givskov. Tel: +45 4525 2768. Fax: +45 45932809.

e-mail: michael.givskov@biocentrum.dtu.dk

\footnotetext{
1 Department of Molecular Microbiology, BioCentrumDTU, Technical University of Denmark, DK-2800 Lyngby, Denmark

2 Lehrstuhl für Mikrobiologie, Technische Universität München, D85350 Freising, Germany

3 Department of Civil Engineering, Technological Institute, North Western University, Evanston, IL 60208-3109, USA

4 School of Microbiology and Immunology, University of New South Wales (UNSW), Australia 2052

5 Department of Clinical Microbiology, University Hospital (Rigshospitalet), DK-2100 Copenhagen, Denmark
}

\begin{abstract}
Novel molecular tools have been constructed which allow for in situ detection of $\mathbf{N}$-acyl homoserine lactone (AHL)-mediated quorum sensing in Pseudomonas aeruginosa biofilms. The reporter responds to AHL activation of LasR by expression of an unstable version of the green-fluorescent protein (Gfp). Gfpbased reporter technology has been applied for non-destructive, single-celllevel detection of quorum sensing in laboratory-based $P$. aeruginosa biofilms. It is reported that a synthetic halogenated furanone compound, which is a derivative of the secondary metabolites produced by the Australian macroalga Delisea pulchra, is capable of interfering with AHL-mediated quorum sensing in $P$. aeruginosa. It is demonstrated that the furanone compound specifically represses expression of a PlasB-gfp reporter fusion without affecting growth or protein synthesis. In addition, it reduces the production of important virulence factors, indicating a general effect on target genes of the las quorum sensing circuit. The furanone was applied to $P$. aeruginosa biofilms established in biofilm flow chambers. The Gfp-based analysis reveals that the compound penetrates microcolonies and blocks cell signalling and quorum sensing in most biofilm cells. The compound did not affect initial attachment to the abiotic substratum. It does, however, affect the architecture of the biofilm and enhances the process of bacterial detachment, leading to a loss of bacterial biomass from the substratum.
\end{abstract}

Keywords: biofilms, quorum sensing inhibitors, green-fluorescent protein

\section{INTRODUCTION}

Many host-associated bacteria use chemical signals to monitor their own species population density and to control expression of specific genes in response to population density. This type of gene regulation is termed quorum sensing (Fuqua et al., 1997) and is a generic phenomenon described in many Gram-negative

Abbreviations: $\mathrm{AHL}, \mathrm{N}$-acyl-homoserine lactone; $\mathrm{BHL}, \mathrm{N}$-butanoyl-Lhomoserine lactone; Gfp, green-fluorescent protein; OdDHL, $N$-[3-oxododecanoyl]-L-homoserine lactone; OHHL, N-[3-oxo-hexanoyl]-L-homoserine lactone; QSC, quorum-sensing-controlled; QSI, quorum sensing inhibitor; Rfp, red-fluorescent protein; SCLM, scanning confocal laser microscopy.
(Eberl, 1999; Greenberg, 1997) and Gram-positive bacteria (Kleerebezem et al., 1997). Many Gram-negative bacteria capable of quorum sensing employ $\mathrm{N}$-acyl homoserine lactones (AHLs) as the signalling compound. The various AHL compounds described in Gram-negative bacteria differ from one another in length and substitutions on their acyl side chains. The signalling molecule is synthesized by a LuxI-type synthase and they bind to a cognate LuxR-type transcriptional activator protein to regulate expression of target genes. At low cell density, the signalling compound is synthesized at a low basal level and is thought to diffuse into the surrounding medium where it becomes diluted. During growth, the AHL accumulates in the medium until a critical threshold concentration is reached. At this concentration, the AHL binds to its cognate 
receptor, which in turn becomes activated and stimulates or represses transcription of target genes.

Pseudomonas aeruginosa, a Gram-negative opportunistic human pathogen, is responsible for persistent and often incurable infections in immunocompromised people and individuals with cystic fibrosis (Hoiby, 2000; Koch \& Hoiby, 1993; Pollack, 1990). The list of $P$. aeruginosa quorum-sensing-controlled (QSC) genes and phenotypes is growing continuously (Glessner et al., 1999; Hassett et al., 1999) and classes of qsc genes are emerging (Whiteley et al., 1999; for reviews, see Passador \& Iglewski, 1995; Pesci \& Iglewski, 1997; Swift et al., 1996; Van Delden \& Iglewski, 1998; Williams et al., 2000).

Two AHL-mediated quorum sensing circuits have been identified in $P$. aeruginosa. The las system consists of lasI, an AHL synthase gene responsible for the synthesis of OdDHL [N-(3-oxo-dodecanoyl)-L-homoserine lactone; 3-oxo-C12-HSL; PAI-1] (Pearson et al., 1994), and lasR which encodes a LuxR-type transcriptional regulator protein (Gambello \& Iglewski, 1991; Passador et al., 1993). The las system has been shown to regulate the expression of several virulence factors, such as extracellular enzymes (LasB elastase, LasA protease, alkaline protease), secondary metabolites (pyocyanin, hydrogen cyanide, pyoverdin), toxins (exotoxin A) and lasI itself. In the $r h l$ system, the $r h l I$ gene product directs the synthesis of BHL ( $N$-butanoyl-L-homoserine lactone; C4-HSL; PAI-2), which, in conjunction with the $r h l R$ gene product, activates transcription of the $r h l A B$ rhamnolipid biosynthesis genes and the rhlI gene itself. The $r h l$ system is also involved in modulating the expression of several of the virulence factors controlled by the las system (Glessner et al., 1999; Pearson et al., 1995).

In the cystic fibrosis lung, $P$. aeruginosa grows primarily as biofilms (Hoiby, 1977; Lam et al., 1980; Singh et al., 2000), which provide protection from the host defence system and from the action of antibiotics (Koch \& Hoiby, 1993). Biofilms are highly structured, surfaceattached communities of cells enclosed in self-produced polymeric matrix. In laboratory-based systems, $P$. aeruginosa forms biofilms several hundred micrometres thick with tower- and mushroom-shaped microcolonies intervened by water channels and void spaces (Costerton et al., 1995; Davies et al., 1998). The current model is that biofilm formation proceeds through a series of programmed events. O'Toole \& Kolter (1998) have demonstrated that flagellar motility and type IV pilimediated twitching motility in $P$. aeruginosa is necessary for surface attachment and colonization. There is increasing evidence that cell-to-cell communication plays a crucial role for the maturation of biofilms, i.e. for the development of a characteristic three-dimensional biofilm architecture. For $P$. aeruginosa it has been demonstrated that the ability to form biofilms in flow chamber systems is affected by the las, but not the $r h l$ quorum sensing system (Davies et al., 1998). While the wild-type formed characteristic microcolonies separated by water channels, the lasI mutant developed only flat, undifferentiated biofilms which exhibited greater sensitivity to the biocide SDS. These results argue in favour of functional overlaps between factors necessary for cell-to-cell signalling, biofilm maturation and bacterial pathogenesis.

Phenotypes regulated by cell-to-cell communication have been proven or suggested to be important for bacterial colonization of eukaryotes (Eberl et al., 1996; Givskov et al., 1996, 1997; Kjelleberg et al., 1999; Piper et al., 1993; von Bodman \& Farrand, 1995). Given the widespread occurrence of AHL-mediated cell-to-cell communication systems, it has been hypothesized that higher organisms may have evolved specific means to interfere with bacterial communication and possibly escape colonization. The Australian marine macroalga Delisea pulchra has been suggested to possess such a countermeasure to bacterial processes (Kjelleberg et al., 1999). The alga produces a number of halogenated furanones (de Nys et al., 1993; Reichelt \& Borowitzka, 1984) which display strong bacterial activities, including antifouling and antimicrobial properties (de Nys et al., 1995 ; Reichelt \& Borowitzka, 1984). Most interestingly, recent reports indicate that some furanones possess AHL-antagonistic activity, which can likely be attributed to a structural similarity to AHLs (Givskov et al., 1996; Manefield et al., 1999, 2000). We, therefore, have initiated research to assess the potential of these furanone compounds as quorum sensing inhibitors (QSIs). This approach may lead to the development of novel non-antibiotic drugs which aim at the attenuation of bacterial virulence rather than killing the pathogen (Givskov et al., 1996).

In the present study, we present new genetic tools that allow monitoring of cell-cell communication in live cells. The system utilizes the green-fluorescent protein (Gfp) of the jellyfish Aequorea victoria for non-invasive, real-time detection of gene expression at the single-cell level without the addition of chemical substrates. Moreover, since the Gfp used has a short half-life, the system allows for repeated measurements of the same cells to continually assess bacterial activity. This opens unprecedented possibilities for in situ studies of quorum sensing and quorum sensing inhibition in ecologically and clinically relevant scenarios (environments). We have applied the technology for on-line detection of quorum sensing in flow-cell-based $P$. aeruginosa biofilms. In addition, we present a novel halogenated furanone compound capable of interfering with $P$. aeruginosa cell-to-cell communication. We demonstrate that the furanone reduces QSC gene expression while having no effect on bacterial protein synthesis or growth. The halogenated furanone reduces the production of several QSC virulence factors and the compound interferes with $P$. aeruginosa biofilm formation.

\section{METHODS}

Bacterial strains. Escherichia coli and P. aeruginosa strains used in this study are listed in Table 1. 
Table 1. Bacterial strains, plasmids and primers used in this study

\begin{tabular}{|c|c|c|}
\hline $\begin{array}{l}\text { Strain/plasmid/ } \\
\text { primer }\end{array}$ & Relevant genotype and characteristics & Source or reference \\
\hline \multicolumn{3}{|l|}{ E. coli } \\
\hline MT102 & $\mathrm{F}^{-}$thi araD139 ara-leus7679 $\Delta\left(\right.$ laclOPZY) galU gal $^{\prime} \mathrm{K} \mathrm{r}^{-} \mathrm{m}^{+} \mathrm{Sm}^{\mathrm{R}}$ & T. Hansen, Novo Nordisk A/S \\
\hline CC118 $\lambda$ pir & $\begin{array}{l}\Delta(\text { ara-leu }) \text { araD } \Delta l a c X 74 \text { galE galK phoA20 thi-1 rps-1 rpoB argE(Amp) } \\
\text { recA thi pro hsdRM } M^{+} \text {RP4-2-Tc:: Mu-Km::Tn7 ipir }\end{array}$ & Herrero et al. (1990) \\
\hline \multicolumn{3}{|c|}{ ( } \\
\hline PAO1 & Wild-type $P$. aeruginosa & Holloway (1955) \\
\hline PAO-JP2 & lasI rhli derivative of $\mathrm{PAO} 1, \mathrm{Hg}^{\mathrm{R}} \mathrm{Tc}^{\mathrm{R}}$ & Pearson et al. (1997) \\
\hline \multicolumn{3}{|c|}{ 然 } \\
\hline pJBA25 & 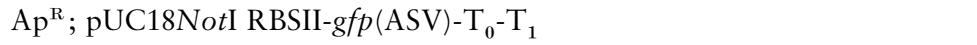 & J. B. Andersen \\
\hline pJBA27 & $\mathrm{Ap}^{\mathrm{R}} ;$ pUC18NotI $\mathrm{P}_{\mathrm{A} 1 / \mathrm{O} 4 / \mathrm{O} 3}-\mathrm{RBSII}-g f p \mathrm{mut} 3 *-\mathrm{T}_{0}-\mathrm{T}_{1}$ & Andersen et al. (1998) \\
\hline pJBA132Gm & $\mathrm{Tc}^{\mathrm{R}} \mathrm{Gm}^{\mathrm{R}} ; \operatorname{luxR} \mathrm{PluxI}-g f p(\mathrm{ASV})$ & Andersen et al. (2001) \\
\hline pUCP22Not & $\mathrm{Ap}^{\mathrm{R}} \mathrm{Gm}^{\mathrm{R}}$; Pseudomonas shuttle and cloning vector, ori $\mathrm{pRO} 1614$ & Herrero et al. (1990) \\
\hline pKDT17 & $\mathrm{Ap}^{\mathrm{R}} ;$ lasB-lacZ Plac-lasR & Pearson et al. (1994) \\
\hline pUTTc & $\mathrm{Ap}^{\mathrm{R}} \mathrm{Tc}^{\mathrm{R}} ; \mathrm{Tn} 5$-based delivery plasmid & de Lorenzo et al. (1990) \\
\hline $\mathrm{p} \operatorname{Tn} 5-\mathrm{Gm}$ & $\mathrm{Ap}^{\mathrm{R}} \mathrm{Gm}^{\mathrm{R}}$; Tn5-based delivery plasmid & Whiteley et al. (2000) \\
\hline pDsRed & $\mathrm{Ap}^{\mathrm{R}} ;$ DsRed expression vector & Clontech Laboratories \\
\hline pMH210 & $\mathrm{Ap}^{\mathrm{R}} \mathrm{Gm}^{\mathrm{R}}$; Plac-dsred fragment of pDsRed cloned into pUCP22Not & This study \\
\hline pTn5-Red & $\mathrm{Ap}^{\mathrm{R}} \mathrm{Tc}^{\mathrm{R}} ; \mathrm{pUTTc}$ carrying Plac-dsred $-\mathrm{T}_{0}-\mathrm{T}_{1}$ & This study \\
\hline pMH306 & $\mathrm{Ap}^{\mathrm{R}} \mathrm{Gm}^{\mathrm{R}} ;$ pUCP22Not carrying $\mathrm{P}_{\mathrm{A} 1 / 04 / 03}-\mathrm{RBSII}-g f p m u t 3 *-\mathrm{T}_{0}-\mathrm{T}_{1}$ & This study \\
\hline pMH391 & $\begin{array}{l}\mathrm{Ap}^{\mathrm{R}} \mathrm{Gm}^{\mathrm{R}} ; \text { Pseudomonas shuttle and } g f p(\mathrm{ASV}) \text { fusion vector with RBSII- } \\
g f p(\mathrm{ASV})-\mathrm{T}_{0}-\mathrm{T}_{1}\end{array}$ & This study \\
\hline pMHLB & $\mathrm{Ap}^{\mathrm{R}} \mathrm{Gm}^{\mathrm{R}} ; \mathrm{pMH} 391$ carrying PlasB-gfp(ASV) & This study \\
\hline pMHLAS & $\mathrm{Ap}^{\mathrm{R}} \mathrm{Gm}^{\mathrm{R}} ; \mathrm{pMH} 391$ carrying PlasB-gfp(ASV) Plac-lasR & This study \\
\hline pTn5-LAS & $\mathrm{Ap}^{\mathrm{R}} \mathrm{Gm}^{\mathrm{R}} ; \mathrm{p} T \mathrm{n} 5$-Gm carrying PlasB-gfp(ASV) Plac-lasR & This study \\
\hline pBAD18 & $\mathrm{Ap}^{\mathrm{R}} ; \operatorname{araC} \mathrm{P}_{\mathrm{BAD}}$ promoter & Guzman et al. (1995) \\
\hline pBADGfp & $\mathrm{Ap}^{\mathrm{R}} \mathrm{Gm}^{\mathrm{R}}$; Pseudomonas shuttle vector with araC $\mathrm{P}_{\mathrm{BAD}^{-}}-g f p(\mathrm{ASV})$ & This study \\
\hline pTn5-BADGfp & $\mathrm{Ap}^{\mathrm{R}} \mathrm{Gm}^{\mathrm{R}} ; \mathrm{pTn} 5-\mathrm{Gm}$ carrying $\operatorname{araC} \mathrm{P}_{\mathrm{BAD}}-g f p(\mathrm{ASV})$ & This study \\
\hline pRK600 & $\begin{array}{l}\mathrm{Cm}^{\mathrm{R}} \text {; ori ColE1 RK2-Mob }{ }^{+} \mathrm{RK} 2-\mathrm{Tra}^{+} \text {; helper plasmid in triparental } \\
\text { conjugations }\end{array}$ & Kessler et al. (1992) \\
\hline \multicolumn{3}{|c|}{ ( } \\
\hline lasB fwd & 5'-GCTCTAGAGCGGCCAGGAAAGCGTGCAA-3' & \\
\hline lasB rev & 5'-GCTGCTGCATGCTTGTTCAGTTCTCCTGGT-3' & \\
\hline lasR fwd & 5'-CGGGATCCGGCACGACAGGTTTCCCGAC-3' & \\
\hline lasR rev & 5'-GCCGGCCAGTGCCAAGCTTGC-3' & \\
\hline $\operatorname{araCP}$ fwd & 5'-GGGTACGTCGACTGATCACCTATGCTACTCCGTCAAGCCG-3' & \\
\hline araCP rev & 5'-GCGCTCGTCGACTGATCAGTTCAAATCCGCTCCCGGCGG-3' & \\
\hline
\end{tabular}

Media. The basic medium was either modified Luria-Bertani (LB) medium (Bertani, 1951) containing $4 \mathrm{~g} \mathrm{NaCl} \mathrm{l}^{-1}$ or $\mathrm{ABt}$ minimal medium $[\mathrm{AB}$ minimal medium (Clark \& Maaløe, 1967) containing $2 \cdot 5 \mathrm{mg}$ thiamine $\left.\mathrm{l}^{-1}\right]$. Antimicrobial agents were added as appropriate at the following concentrations: gentamicin, $15 \mu \mathrm{g} \mathrm{ml}^{-1}$ for $E$. coli and $60 \mu \mathrm{g} \mathrm{ml}^{-1}$ for $P$. aeruginosa; ampicillin, $100 \mu \mathrm{g} \mathrm{m}^{-1}$ for E. coli; carbenicillin, $300 \mu \mathrm{g} \mathrm{ml}^{-1}$ for $P$. aeruginosa; tetracycline, $60 \mu \mathrm{g} \mathrm{ml} \mathrm{m}^{-1}$ for $P$. aeruginosa.

Plasmids and DNA manipulations. The plasmids used in this study are listen in Table 1 . DNA treatment with modifying enzymes and restriction endonucleases (Gibco BRL), ligation of DNA fragments with T4 ligase (Gibco BRL) and transformation of E. coli were performed using standard methods (Sambrook et al., 1989). Plasmid DNA was isolated with the Spin Miniprep kit (Qiagen) and DNA fragments were excised and purified from agarose gels using GFX DNA and the Gel
Band Purification kit (Amersham Pharmacia Biotech). PCR was carried out on a Biometra T3 thermocycler using the Expand High Fidelity PCR kit (Boehringer Mannheim). Transformation of $P$. aeruginos $a$ was performed according to the method described by Diver et al. (1990).

The transcriptional fusion vector pMH391 was constructed by inserting the 1765 bp NotI fragment containing the RBSII$g f p$ (ASV) $-\mathrm{T}_{0}-\mathrm{T}_{1}$ cassette of $\mathrm{pJBA} 25$, as described by Andersen et al. (1998), into NotI-digested pUCP22Not.

A translational fusion between the $\mathrm{N}$-terminal part of las $B$ and an unstable variant of the $g f p$ gene was constructed. The first codon of the las $B$ gene was maintained and fused to the $g f p$ (ASV) ORF devoid of the start codon (Andersen et al., 1998). The fusion retains the las $B$ promoter and the $5^{\prime}$ untranslated region of the las $B$ transcript and ensures that the native ribosome-binding site (RBS) and the spacing to the start 
(a)

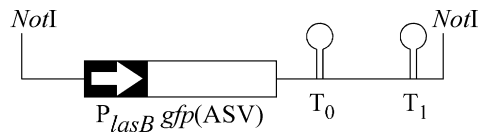

(b)

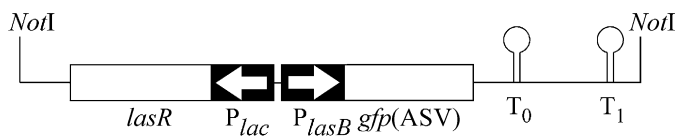

(c)

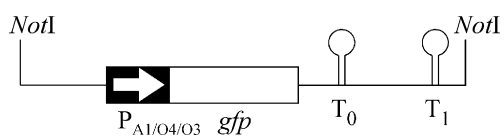

(d)

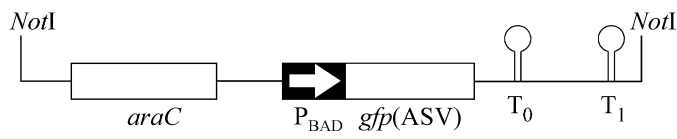

Fig. 1. Schematic drawings of las $B$ reporter fusions (not to scale). (a) lasB-gfp(ASV) translational fusion vector pMHLB. (b) pMHLAS with las $B$ fusion and lasR expressed from the lac promoter. (c) gfp expression cassette of pMH306. (d) LArabinose-controlled gfp(ASV) expression cassette of pBADGfp. The indicated Notl fragments are maintained on a Pseudomonas shuttle vector of the pUCP series and on the miniTn5 delivery vector, pTn5-Gm. The genetic components are: PlasB, elastase (LasB) promoter fragment; gfp(ASV), gene encoding the unstable Gfp(ASV); $T_{0}$, transcriptional terminator from phage $\lambda, T_{1}$, transcriptional terminator from $r$ rnB operon

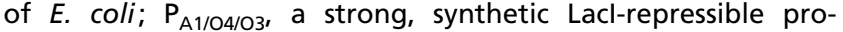
moter; $\operatorname{araC} \mathrm{P}_{\mathrm{BAD}}$, the promoter of the $E$. coli $\operatorname{araBAD}$ operon and the gene encoding the positive and negative regulator of this promoter, araC.

codon is preserved and, therefore, that the activity of the reporter gene fusion closely reflects the expression of the las $B$ gene. The quorum sensing reporter system, pMHLAS, was constructed by a two-step cloning procedure. The PlasB$g f p($ ASV) translational fusion was made by amplifying a $348 \mathrm{bp}$ PCR product starting $345 \mathrm{bp}$ upstream of the lasB initiation codon, using the primers las $B$ fwd and las $B$ rev (Table 1 ) and chromosomal DNA of $P$. aeruginosa PAO1 as template. The PCR fragment was subsequently digested with $X b a \mathrm{I}$ and $S p h \mathrm{I}$ and inserted into the corresponding site of pMH391. This gave rise to the plasmid pMHLB (Fig. 1a) which carries the translational PlasB-gfp(ASV) followed by translational stop codons in all three reading frames and two strong transcriptional terminators (Andersen et al., 1998).

To enhance the sensitivity of the quorum sensing monitor, the lasR gene under control of the lac promoter was inserted upstream of PlasB-gfp(ASV). The lac promoter was chosen to drive las $R$ expression since previous studies have demonstrated that lasR under its own promoter was insufficient to activate the lasB promoter in the presence of OdDHL in E. coli (Pearson et al., 1995). The presence of lasR on the monitor plasmid allows use of very sensitive E. coli-based monitor strains harbouring the construct in high copy-numbers. A 1002 bp BamHI fragment containing the Plac-lasR expression cassette was generated by PCR amplification with the primer set lasR fwd and lasR rev (Table 1) and with pKDT17 as template. The fragment was inserted into the unique BamHI site of pMHLB. The resulting plasmid, pMHLAS, contained divergent transcribed Plac-lasR and PlasB-gfp(ASV) fusions on a 3126 bp fragment flanked by NotI restriction sites (Fig. $1 b)$.

The NotI cassette was excised from pMHLAS and inserted into the unique NotI site of the pTn5-Gm vector to create pTn5-LAS.

A vector for constitutive Gfp expression in $P$. aeruginosa was constructed by cloning the $2 \cdot 0 \mathrm{~kb}$ NotI fragment of pJBA27 (Andersen et al., 1998) containing the $\mathrm{P}_{\mathrm{A} 1 / \mathrm{O} 4 / \mathrm{O} 3}$-RBSIIgfpmut $3 *-\mathrm{T}_{0}-\mathrm{T}_{1}$ cassette into NotI-digested pUCP22Not. The resulting plasmid was termed pMH306 (Fig. 1c).

The $\operatorname{araC}-\mathrm{P}_{\mathrm{BAD}}$-controlled $g f p(\mathrm{ASV})$ expression vector was constructed by PCR amplification of a $1658 \mathrm{bp}$ fragment containing the araC- $\mathrm{P}_{\mathrm{BAD}}$ region using the primers ara $\mathrm{CP}$ fwd and ara CP rev (Table 1 ) and pBAD18 as template. The ara $C$ $\mathrm{P}_{\mathrm{BAD}}$ fragment was digested with $B c l \mathrm{I}$ and $\mathrm{XbaI}$ and then ligated into the $B a m \mathrm{HI}-\mathrm{Xba \textrm {I }}$ site of $\mathrm{pMH} 391$, giving rise to pBADGfp (Fig. 1d). The araC- $\mathrm{P}_{\mathrm{BAD}}-g f p$ (ASV) cassette was subsequently excised as a Not I fragment and moved into the corresponding site of pTn5-Gm to give pTn5-BADGfp.

The plasmid used to provide a red-fluorescent colour tag on bacteria was constructed as follows. pDsRed was digested with NotI, polished with T4 DNA polymerase and digested with PvuII. A 916 bp blunt-ended fragment containing the dsred gene under the lac promoter was isolated and inserted into the blunt-ended EcoRI-HindIII site of pMH391. This resulted in $\mathrm{pMH} 210$ with Plac-dsred followed by translational stop codons in all three reading frames and two strong transcriptional terminators. The dsred expression cassette was excised as a $1916 \mathrm{bp}$ Not I fragment and moved into the corresponding site of the pUTTc delivery vector to yield pTn5-Red. The lac promoter of E. coli acts as a constitutive promoter in Pseudomonas spp. due to the absence of lac repressor activity (Andersen et al., 1998).

The reporter cassettes were inserted at random positions in the chromosomes of $P$. aeruginosa PAO1 and PAO-JP2 by triparental mating. The selected transconjugants with random insertion of the mini-Tn5 elements showed no sign of phenotypic changes compared to the parental strains when tested in liquid medium or flow-chamber biofilms.

Furanone compound. Furanone 56 was made by chemical synthesis as described by Manny et al. (1997).

AHL and furanone bioassay. Strains were grown exponentially in LB or ABt medium supplemented with $0.5 \%$ glucose at $30{ }^{\circ} \mathrm{C}$, shaking at 250 r.p.m. At an $\mathrm{OD}_{600}$ of approximately $0 \cdot 8$, the cultures were diluted and split into subcultures in glass culture flasks. AHLs and furanone 56 were added to appropriate concentrations and the cultures were further incubated at $30^{\circ} \mathrm{C}$ with vigorous shaking. Culture samples were retrieved at various time intervals and green fluorescence was measured with a fluorometer (model RF-1501; Shimadzu) set at an excitation wavelength of $475 \mathrm{~nm}$ and emission wavelength of $515 \mathrm{~nm}$. Relative fluorescence was calculated as green fluorescence normalized to $1 \mathrm{ml}$ culture divided by $\mathrm{OD}_{600}$.

$\boldsymbol{P}$. aeruginosa biofilms. Biofilms were grown at $30{ }^{\circ} \mathrm{C}$ in threechannel flow cells (Christensen et al., 1999) with individual channel dimensions of $0.3 \times 4 \times 40 \mathrm{~mm}$ supplied with $\mathrm{ABt}$ minimal medium supplemented with $2 \%$ LB. The flow system was assembled and prepared as described by Christensen $e t$ al. (1999). The substratum consisted of a microscope glass coverslip (Knittel $24 \times 50 \mathrm{~mm}$ st1; Knittel Gläser). Cultures for inoculation of the flow channels were prepared as follows. 
(a)

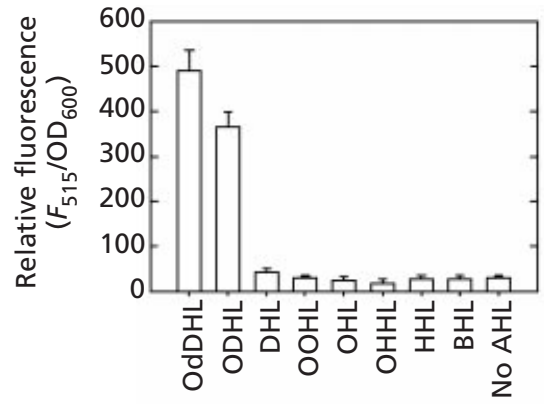

(b)

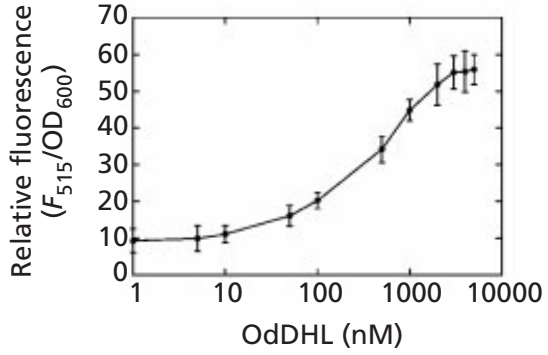

(c)

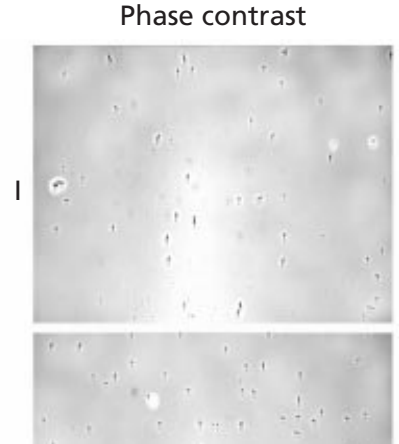

II

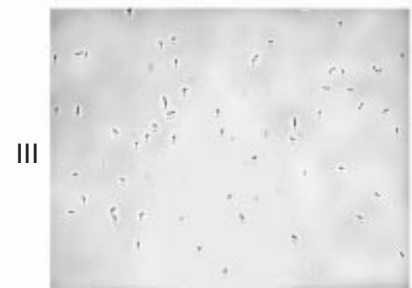

Epifluorescence

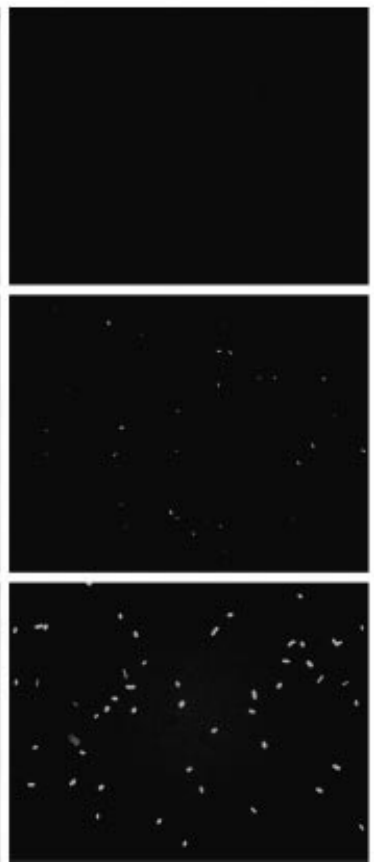

Fig. 2. Characterization of lasB-based quorum sensing reporter. (a) Induction of pMHLAS in E. coli MT102 by different AHL compounds, all at $1000 \mathrm{nM}$. The relative green fluorescence emitted by the cells was calculated as the fluorescence at $515 \mathrm{~nm}$ divided by $\mathrm{OD}_{600}$. The $\mathrm{AHL}$ compounds assayed were: $\mathrm{OdDHL}, \mathrm{ODHL}$ [ $N$-(3-oxo-decanoyl)-L-homoserine lactone], DHL ( $\mathrm{N}$-decanoyl-L-homoserine lactone), OOHL [N-(3-oxo-octanoyl)-L-homoserine lactone], OHL ( $\mathrm{N}$-octanoyl-Lhomoserine lactone), OHHL, HHL ( $N$-hexanoyl-L-homoserine lactone) and BHL. The results are mean values \pm SEM of three independent experiments. (b) OdDHL-mediated induction of the PlasB-gfp(ASV) Plac-lasR reporter cassette on a mini-Tn5 transposon integrated into the chromosome of PAO-JP2. The results are mean values \pm SEM of three independent experiments. (c) Phase-contrast and epifluorescence microphotographs of OdDHL-induced PAO-JP2 cells containing the mini-Tn5-based reporter system. The OdDHL concentrations used were 10 (I), 100 (II) and $1000 \mathrm{nM}$ (III).

$P$. aeruginosa strains were streaked on LB plates with the appropriate antibiotics and incubated for $24 \mathrm{~h}$ at $37^{\circ} \mathrm{C}$. From each plate a single colony was used for inoculation of $10 \mathrm{ml}$ ABt with $10 \%$ LB. The cultures were grown at $30{ }^{\circ} \mathrm{C}$ for $18 \mathrm{~h}$ before they were diluted to an $\mathrm{OD}_{600}$ of $0 \cdot 1$ in sterile $0.9 \%$ $\mathrm{NaCl}$ and used for inoculation of the flow channels. Medium flow was kept at a constant rate of $3 \mathrm{ml} \mathrm{h}^{-1}$, equivalent to a mean flow velocity of $0.7 \mathrm{~mm} \mathrm{~s}^{-1}$, using a Watson-Marlow $205 \mathrm{~S}$ peristaltic pump. Biofilms were grown for $24 \mathrm{~h}$ before being shifted to media containing AHL and furanone.

Measurements of virulence factors. PAO-JP2 was grown in $\mathrm{LB}$ medium at $37^{\circ} \mathrm{C}$ with shaking at 250 r.p.m. to an $\mathrm{OD}_{600}$ of $1 \cdot 0$. The culture was divided into subcultures to which was added OdDHL $(1 \mu \mathrm{M})$ and BHL $(3 \mu \mathrm{M})$, individually or in combination, and 0,3 or $5 \mu \mathrm{g}$ furanone $56 \mathrm{ml}^{-1}$. The cultures were grown for an additional $4 \mathrm{~h}$ at $37^{\circ} \mathrm{C}$. Proteolytic activity was measured as described by Ayora \& Götz (1994). Azocasein $(250 \mu \mathrm{l}, 2 \%$; Sigma $)$ in $50 \mathrm{mM}$ Tris $/ \mathrm{HCl}$ and sterile-filtered $(0 \cdot 2 \mu \mathrm{m}$ pore size $)$ supernatant $(150 \mu \mathrm{l})$ were incubated for $4 \mathrm{~h}$ at $4{ }^{\circ} \mathrm{C}$. After precipitation of undigested substrate with trichloroacetic acid $(1.2 \mathrm{ml}, 10 \%)$ for $15 \mathrm{~min}$, followed by 10 min centrifugation at 10000 r.p.m., $\mathrm{NaOH}(1.4 \mathrm{ml}, 1 \mathrm{M})$ was added to the supernatant. The relative protease activity was measured as $A_{440}$ of the supernatant divided by the $\mathrm{OD}_{600}$ of the culture.

The chitinase activity assay was performed as described by the manufacturer (Loewe Biochemica). Supernatant $(560 \mu \mathrm{l})$ of cultures prepared as described for the elastase assay was mixed with carboxymethyl/chitin/remazol brilliant violet $(200 \mu \mathrm{l})$ and sodium phosphate buffer $(40 \mu \mathrm{l}, 1 \mathrm{M}, \mathrm{pH} 7 \cdot 5)$. The reaction mixture was incubated for $18 \mathrm{~h}$ at $40^{\circ} \mathrm{C}$ in a waterbath. The reaction was stopped by the addition of $\mathrm{HCl}$ $(200 \mu \mathrm{l}, 2 \mathrm{M})$ and kept for $15 \mathrm{~min}$ on ice. After centrifugation (10 min at 15000 r.p.m.), the $A_{550}$ of the supernatant was measured. Relative chitinase activity was calculated as $A_{550} /$ $\mathrm{OD}_{600}$ normalized to $1 \mathrm{ml}$ supernatant.

Scanning confocal laser microscopy (SCLM). Microscopic inspection and image acquisition were performed on a scanning confocal laser microscope (model TCS4D; Leica Lasertechnik) equipped with a $63 \times / 1.32-0 \cdot 6$ oil objective. The microscope was equipped with a motorized and programmable $x y$-stage which was used for monitoring single colonies during the biofilm experiments. At the beginning of each online experiment, the microscope was programmed to track single randomly selected microcolonies; the sensitivity of photo multipliers and the laser intensity were adjusted and thereafter kept constant throughout the duration of the experiments. Image scanning was carried out using the 488 and $568 \mathrm{~nm}$ lines of an $\mathrm{Ar} / \mathrm{Kr}$ laser for detection of Gfp and red-fluorescent protein ( $\mathrm{Rfp}$ ), respectively. Visualization of captured images was performed using the IMARIS software package (Bitplane) running on a Silicon Graphics Indigo 2 workstation. 


\section{RESULTS}

\section{Construction and characterization of lasB-based AHL monitor}

Our genetic construct for detection of AHL signal molecules relies on the availability of a promoter that is transcriptionally controlled by an AHL-activated LuxRtype receptor protein. Several target genes of the las and $r h l$ quorum sensing systems of $P$. aeruginosa have been identified (Ochsner \& Reiser, 1995; Passador et al., 1993; Pearson et al., 1997; Whiteley et al., 1999; Winson et al., 1995). For the purpose of OdDHL detection, we have chosen the well-characterized and tightly regulated las $B$ promoter. Several regulatory elements of the las $B$ promoter such as putative regulatory sequences have been described (Anderson et al., 1999; Fukushima et al., 1997; Gray et al., 1994; Rust et al., 1996). Previous studies using a PlasB-lacZ transcriptional fusion in E. coli MG4 have demonstrated a 63-fold induction of the promoter in response to OdDHL addition (Gray et al., 1994).

We have constructed a reporter system consisting of a translational fusion of the lasB promoter to a gene encoding an unstable variant of Gfp, Gfp(ASV) (Andersen et al., 1998). Expression of the reporter is controlled by LasR from $P$. aeruginosa in conjunction with OdDHL. Several plasmid-based systems which feature high as well as low copy numbers have been used to accommodate the present reporter cassette in $P$. aeruginosa. These include the pUCP series of Pseudomonas shuttle cloning vectors (Bloemberg et al., 1997; West et al., 1994) and mini-Tn5 transposon systems for chromosomal integration (de Lorenzo et al., 1990). The copy number of each system in $P$. aeruginosa is 10 and 1 , respectively (de Lorenzo et al., 1990; Schweizer, 1991).

Initially, the lasB-gfp(ASV) translational fusion (OdDHL sensor) was thoroughly characterized with respect to its sensitivity and specificity. A culture of $E$. coli hosting the pMHLAS monitor plasmid was diluted and split into several subcultures which were then supplemented with AHLs at concentrations ranging from 0 to $1000 \mathrm{nM}$. Not surprisingly, the most efficient inducer of the monitor was OdDHL, the cognate signal molecule of the las quorum sensing system. A closely related analogue, ODHL (3-oxo-C10-HSL), also activated lasB expression, albeit at a lower level. The (a)

(c)
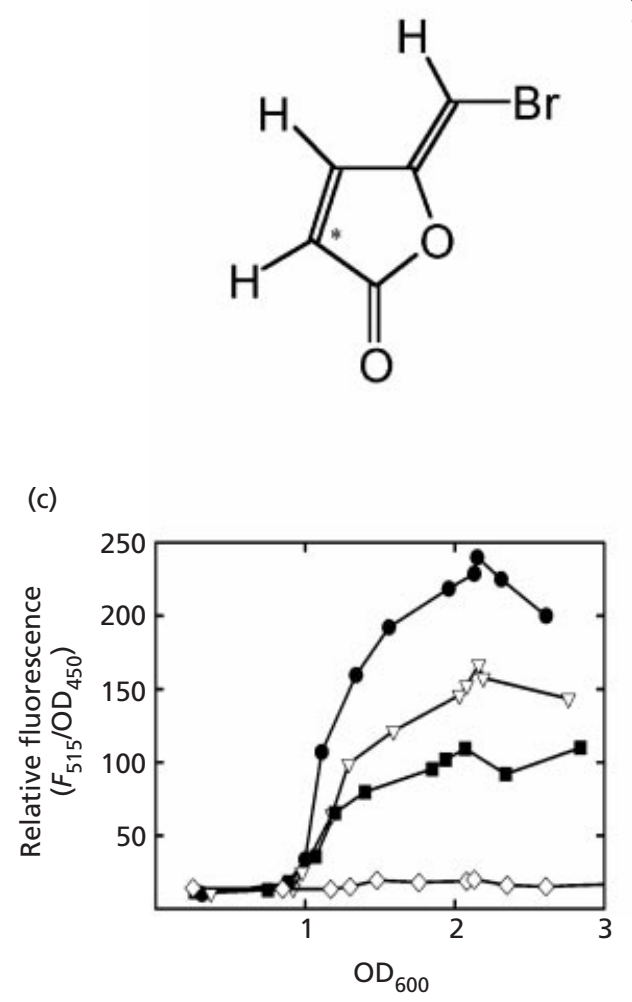

(b)

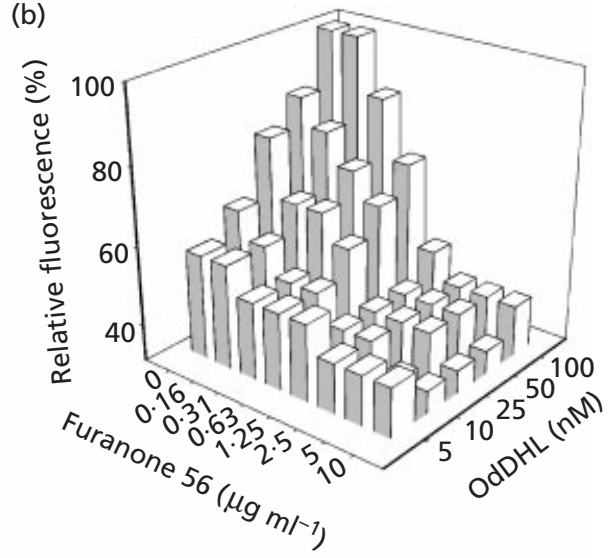

(d)

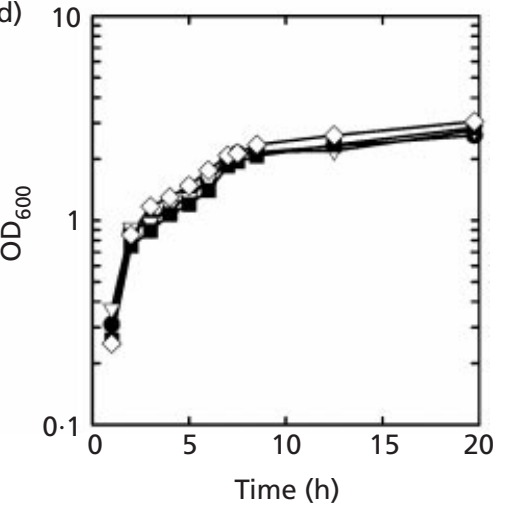

Fig. 3. Inhibition of quorum sensing by furanone 56. (a) Molecular structure of furanone 56 (MW $175 \mathrm{~g} \mathrm{~mol}{ }^{-1}$ ). The asterisk indicates position 3 on the furanone ring. (b) Response of PAO-JP2 mini-Tn5-PlasB-gfp(ASV) Plac-lasR to OdDHL and furanone 56. The fluorescence signal has been normalized to $100 \%$ for $100 \mathrm{nM}$ OdDHL and $0 \mu \mathrm{g}$ furanone $56 \mathrm{ml}^{-1}$. (c) Induction of the mini-Tn5-based PlasB-gfp(ASV) reporter in wild-type $P$. aeruginosa PAO1 in the presence of 0 (०), $5(\nabla)$ or $10 \mu \mathrm{g}$ furanone $56 \mathrm{ml}^{-1}(\square)$; $\diamond$, PAO1 with the pMH391 vector control. (d) Growth of P. aeruginosa PAO1 in the presence of furanone 56 [symbols as for (c)]. 

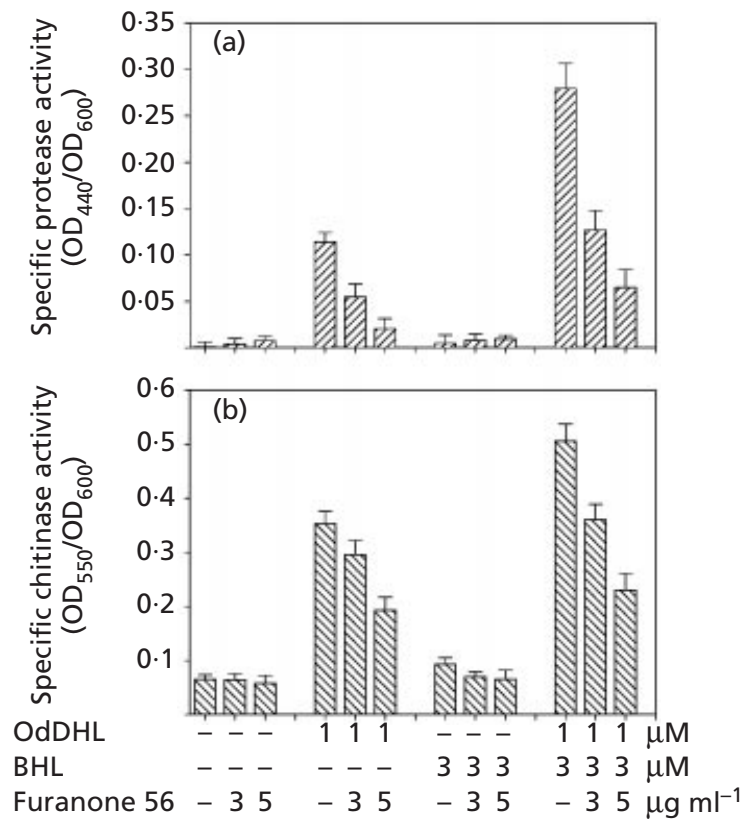

Fig. 4. $P$. aeruginosa $\mathrm{PAO}-\mathrm{JP} 2$ virulence factor production in the presence of OdDHL and furanone 56. (a) Elastase activity; (b) chitinase activity.

remaining AHL compounds did not induce significant expression of the reporter gene at a concentration of $1 \mu \mathrm{M}$ (Fig. 2a). When the pMHLAS-based reporter system was hosted by PAO-JP2, the OdDHL concentration required for half-maximal activation of the lasB-gfp(ASV) fusion was $8 \mathrm{nM}$ (data not shown). When the PlasB-gfp(ASV) reporter system was inserted in the chromosome of PAO-JP2 in single copy, the OdDHL concentration required for half-maximal activation of las $B$ expression was approximately $250 \mathrm{nM}$ (Fig. 2b). Green-fluorescent cells were visible by epifluorescence microscopy at a minimal OdDHL concentration of $50 \mathrm{nM}$ (Fig. 2c).

\section{Furanone-mediated inhibition of quorum sensing}

Furanone compounds produced by the Australian macroalga $D$. pulchra have been shown to possess quorum sensing inhibitory properties as well as interfering with complex surface-dependent phenomena such as swarming motility and biofilm formation of Serratia liquefaciens (Givskov et al., 1996; Lindum et al., 1998; Manefield et al., 1999, 2000). Natural furanone compounds have a rather limited effect on $P$. aeruginosa when tested individually (data not shown). However, natural QSI compounds can be further modified by means of combinatorial chemistry which is a highly efficient method of generating a large number of analogues for screening purposes. One such synthetic furanone compound, termed furanone 56, is characterized by a lack of side chain at position 3 on the furanone ring. This compound only contains one bromine substitution at the methylene group and no bromine substitution on the furanone ring (Fig. 3a).

To investigate whether the furanone compound efficiently inhibited the las quorum sensing system, planktonic cultures of PAO-JP2 cells harbouring the PlasB-gfp(ASV) reporter were subjected to a range of furanone 56 and OdDHL concentrations. At a concentration of $1.25 \mu \mathrm{g} \mathrm{ml}^{-1}(7 \cdot 1 \mu \mathrm{M})$ furanone 56 inhibited lasB-gfp(ASV) expression at a wide range of OdDHL concentrations (Fig. $3 \mathrm{~b}$ ). In the presence of $100 \mathrm{nM}$ OdDHL about $2 \mu \mathrm{g}$ furanone $56 \mathrm{ml}^{-1}(11.4 \mu \mathrm{M})$ was required to reduce fluorescence by more than $50 \%$. However, complete inhibition was not attained at any of the tested concentrations. It is noteworthy that the inhibitory effect of furanone 56 was relieved at increased concentrations of OdDHL. These results clearly demonstrate that lasB-gfp(ASV) expression is stimulated by OdDHL, while furanone 56 antagonizes this activation.

The PlasB-gfp(ASV) reporter was inserted into the chromosome of wild-type $P$. aeruginosa. Expression of lasB-gfp(ASV) expression was followed along the growth curve in the presence of furanone 56. Fig. 3(c) shows that lasB-gfp(ASV) expression was induced in a cell-density-dependent manner. The quorum size for las $B$ - $g f p$ (ASV) induction corresponded to a cell density slightly above $\mathrm{OD}_{600}$ of $1 \cdot 0$, which is in agreement with other reports (Brumlik \& Storey, 1992). The data show that $5 \mu \mathrm{g}$ furanone $\mathrm{ml}^{-1}(28.5 \mu \mathrm{M})$ caused a $40 \%$ reduction in lasB-gfp(ASV) expression in wild-type $P$. aeruginosa; $10 \mu \mathrm{g}$ furanone $\mathrm{ml}^{-1}$ caused a $60 \%$ reduction.

To determine if the furanone compound worked specifically on the las quorum sensor and not indirectly by disruption of primary metabolic functions, we followed growth as optical density of $P$. aeruginosa PAO1 in the presence of furanone 56. Fig. 3(d) shows that the furanone in concentrations used for this study had no or only little effect on growth. A similar assay with $P$. aeruginosa PAO-JP2 showed no effect on growth rate (data not shown). Furthermore, we tested whether the furanone affected $P$. aeruginosa protein synthesis. The wild-type $P$. aeruginosa PAO1 strain containing the constitutive Gfp expression vector pMH306 was grown in the presence of furanone 56 at concentrations from 0 to $10 \mu \mathrm{g} \mathrm{ml}^{-1}$. Gfp expression (fluorescence/ $\mathrm{OD}_{600}$ ) was unaffected throughout the growth cycle by the presence of the furanone compound (data not shown).

\section{Effect of the furanone in a heterologous background}

The direct regulation exerted by the las regulon on las $B$ expression has been well described in numerous studies (Gambello \& Iglewski, 1991; Pearson et al., 1994, 1997). Regulatory complexity is added by the observation that the las quorum sensing circuit itself is subject to global regulators (Albus et al., 1997; Whiteley et al., 2000) and that las $B$ expression is also controlled by regulators other than LasR (Brumlik \& Storey, 1992; Pesci et al., 1999; Schlictman et al., 1995). It was therefore important 
$0 \mathrm{~h}$
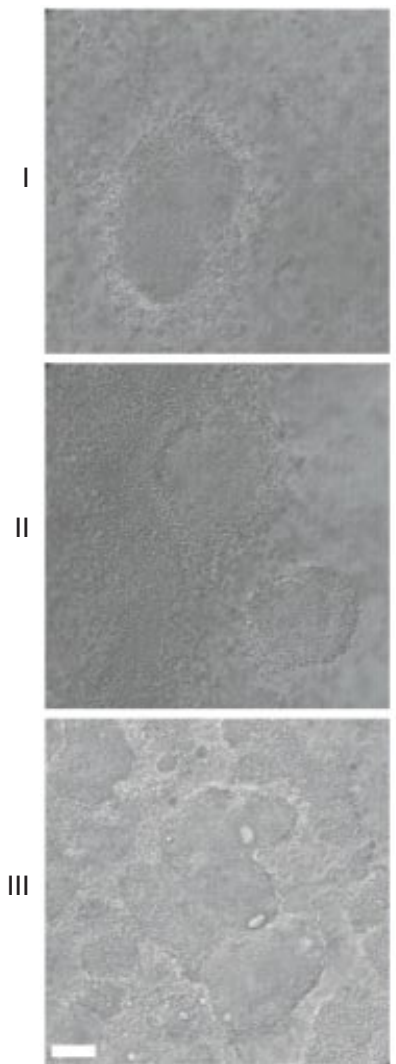
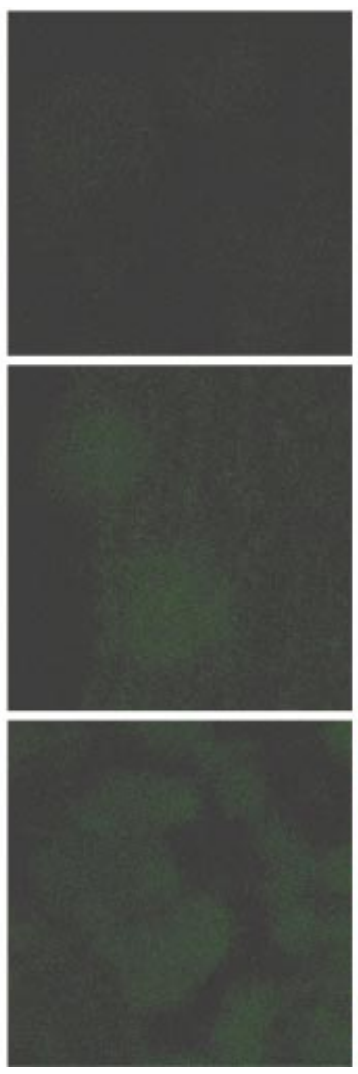

$3 \mathrm{~h}$
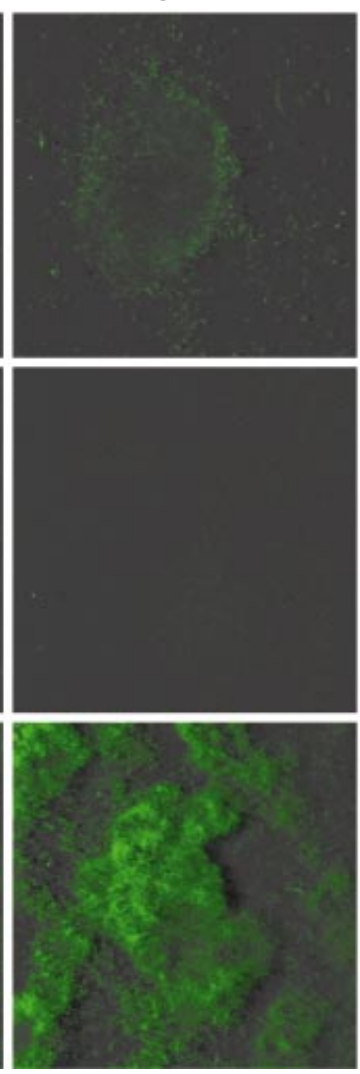

$6 \mathrm{~h}$
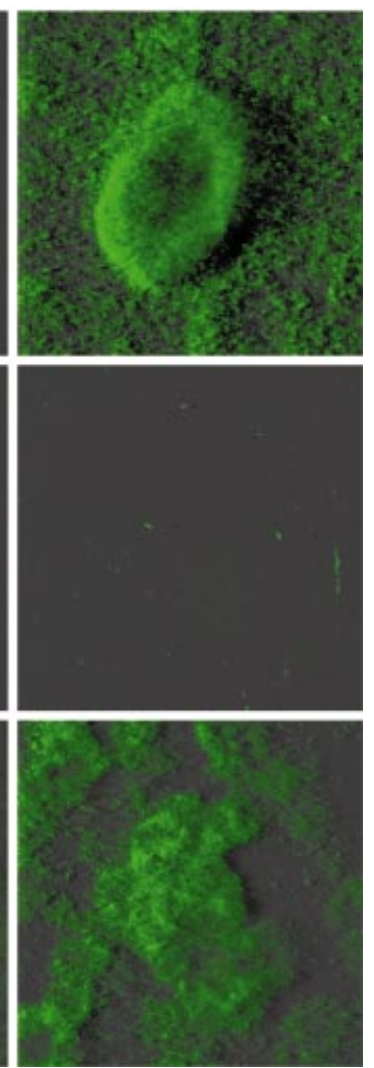

Fig. 5. Inhibition of OdDHL-mediated signalling in $P$. aeruginosa biofilm. Twenty-four-hour-old biofilms of $P$. aeruginosa PAO-JP2 carrying the mini-Tn5-based PlasB-gfp(ASV) Plac-lasR reporter were established in flow cells. ABt-LB medium was switched to contain $40 \mathrm{nM}$ OdDHL (I), $40 \mathrm{nM}$ OdDHL and $2 \mu \mathrm{g}$ furanone $56 \mathrm{ml}^{-1}$ (II) and $80 \mathrm{nM}$ OdDHL and $2 \mu \mathrm{g}$ furanone $56 \mathrm{ml}^{-1}$ (III). Prior to the switch $(0 \mathrm{~h})$, the microscope was programmed to track selected microcolonies. Reflection and epifluorescence images were recorded by SCLM during the $8 \mathrm{~h}$ on-line experiment. Bar, $20 \mu \mathrm{m}$.

to rule out the possibility that the QSI effect observed is not caused by furanone interaction with higher levels of control. Since there is no AHL-based quorum sensing system present in E. coli (Williams et al., 2000), this bacterium provides an unbiased and well defined genetic background for studying the direct effects of the furanone on the $P$. aeruginosa las quorum sensing system. We repeated the above-described experiments using E. coli MT102 as a heterologous host for the reporter system. The QSI activity of the furanone was observed in this background as well (data not shown). The E. coli strain harbouring the lasB reporter showed increased responsiveness to OdDHL (approx. 10fold; see Fig. 2). This is likely to be attributed to the increased copy number of the reporter plasmid. The furanone had no effect on the growth of E. coli MT102 (data not shown).

\section{Effect of furanone 56 on virulence factor production}

The experiments presented above utilized a reporter fusion to the las $B$ promoter to study the effect of OdDHL and furanone 56. An obvious limitation to this approach is the restriction of analysis to the level of transcription. We therefore investigated the effect of the furanone directly on production of the QSC virulence factors elastase and chitinase (Passador et al., 1993; Winson et al., 1995). Fig. 4 demonstrates that $1 \mu \mathrm{M}$ OdDHL induced elastase and chitinase activity in $P$. aeruginosa PAO-JP2. Virulence factor production was further increased by simultaneous addition of $3 \mu \mathrm{M}$ BHL. The addition of BHL alone did not induce elastase or chitinase expression. The presence of 3 or $5 \mu \mathrm{g}$ furanone $56 \mathrm{ml}^{-1}$ reduced the elastase and chitinase activity.

\section{Inhibition of AHL-mediated signalling in $P$. aeruginosa biofilms}

The lasB-gfp(ASV) reporter was integrated into the chromosome of PAO-JP2 to ensure stable segregation and a constant gene dosage of the reporter system. The strain was grown in flow cells for $24 \mathrm{~h}$ in ABt-LB medium and a $10-15 \mu \mathrm{m}$ thick biofilm developed. The medium was subsequently switched to ABt-LB containing the appropriate AHL and furanone concentrations. The development of green fluorescence was monitored on-line by SCLM for $8 \mathrm{~h}$. Fig. 5 shows that 
the microcolonies were non-fluorescent prior to the switch of medium. When switched to medium containing $40 \mathrm{nM}$ OdDHL, expression of the las $B-g f p$ (ASV) reporter fusion was induced and was visible in single cells within $4 \mathrm{~h}$. Switching to a medium containing $40 \mathrm{nM}$ OdDHL and $2 \mu \mathrm{g}$ furanone $56 \mathrm{ml}^{-1}$ did not lead to induction of green fluorescence in the time course of the experiment. However, green fluorescence was induced by $80 \mathrm{nM}$ OdDHL and $2 \mu \mathrm{g}$ furanone $56 \mathrm{ml}^{-1}$. Induction of green fluorescence was abolished in medium containing $80 \mathrm{nM} \mathrm{OdDHL}$ and $4 \mu \mathrm{g}$ furanone $\mathrm{ml}^{-1}$ (data not shown), but was observed in the presence of $150 \mathrm{nM}$ OdDHL and $4 \mu \mathrm{g}$ furanone $56 \mathrm{ml}^{-1}$. No green fluorescence was observed in the presence of $4 \mu \mathrm{g}$ furanone $56 \mathrm{ml}^{-1}$ alone (data not shown).

To determine if the furanone-mediated inhibition of green fluorescence is due to subtle non-specific effects on protein synthesis when the bacteria are growing in a biofilm, we examined expression of green fluorescence in cells harbouring the araC- $\mathrm{P}_{\mathrm{BAD}^{-}}-g f p$ (ASV) cassette induced by suboptimal levels of $\mathrm{L}$-arabinose $(0 \cdot 2 \%)$. The cells became green-fluorescent within $2 \mathrm{~h}$ after induction. The presence of furanone 56 at concentrations below $10 \mu \mathrm{g} \mathrm{ml}^{-1}$ had no effect on Gfp expression (data not shown).

\section{Furanone 56 represses las $B$ expression in wild-type $P$. aeruginosa biofilms}

Wild-type $P$. aeruginosa (PAO1) carrying a chromosomally integrated lasB-gfp(ASV) reporter system was grown in flow cells similar to the PAO-JP2-based reporter strain. We focused on studying the effect of furanone 56 in long-term biofilm experiments. In favour of this approach is the observation by Davies et al. (1998) that quorum sensing is involved in maturation of $P$. aeruginosa biofilms (up to 2 weeks old). To support such long-term cultivation, the biofilm medium was modified to contain $0.3 \mathrm{mM}$ glucose instead of $2 \% \mathrm{LB}$ as carbon source. In addition, the recently available Rfp derived from the Indopacific sea anemone Discosoma was employed to provide a red-fluorescent tag on the biofilm bacteria. A mini-Tn5 transposon with the dsred gene under the control of the strong constitutive lac promoter was inserted into the chromosome of PAO1 containing the las $B$ reporter system.

The dual-labelled PAO1 strain was inoculated and grown in flow cells in the absence and presence of $5 \mu \mathrm{g}$ furanone $56 \mathrm{ml}^{-1}$. The flow cells were inspected daily for $10 \mathrm{~d}$ and scanning confocal photomicrographs were captured (Figs 6 and 7). For clarity, the green and redfluorescent signals from the same area of the biofilm are shown separately. Because the cells constitutively express Rfp, the red colour correlates with cell mass, whereas the green fluorescence indicates active transcription of the las $B-g f p(\mathrm{ASV})$ reporter gene in response to on-going bacterial communication. We observed that the las $B$ reporter in $P$. aeruginosa $\mathrm{PAO} 1$ was activated in a cell-density-dependent manner as small microcolonies
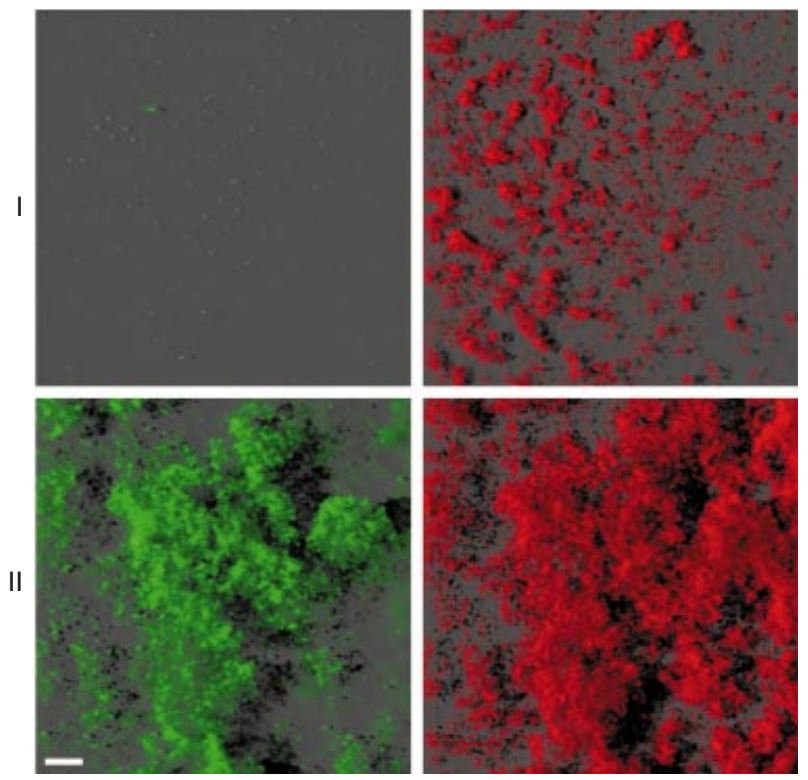

Fig. 6. Cell-density-dependent activation of the PlasB-gfp(ASV) reporter in $P$. aeruginosa PAO1 biofilm. Green fluorescence indicates active transcription of the QSC las $B$ gene. Red fluorescence arises from constitutive expression of the dsred gene and, therefore, correlates to bacterial biomass accumulation at the substratum (right panels). Simulated fluorescence projections generated by SCLM after 12 (I) and $48 \mathrm{~h}$ (II) post-inoculation. Bar, $20 \mu \mathrm{m}$. The medium was ABt minimal medium containing $0.3 \mathrm{mM}$ glucose.

did not fluoresce green in contrast to larger microcolonies, which fluoresced bright-green (Fig. 6).

As evident from Fig. 7, early biofilm formation (day 1 ) is not or is only slightly affected by the furanone, though bacterial signalling appeared to be greatly reduced. By day 7 , the untreated biofilm had grown to a mean thickness of $61 \pm 6 \mu \mathrm{m}$ and bright green fluorescence was emitted by the cells. In contrast, the furanone-treated biofilm was $23 \pm 4 \mu \mathrm{m}$ thick and cells were far less greenfluorescent. Complete inhibition of the lasB-gfp(ASV) reporter in all biofilm bacteria by addition of furanone in concentrations which had no effect growth $(<10 \mu \mathrm{g}$ furanone $56 \mathrm{ml}^{-1}$ ), was not achievable.

\section{Repression of LuxR-activated QSC gene transcription}

We speculated that the AHL-antagonistic properties of furanone 56 were specific to the $P$. aeruginosa las quorum sensing system. To test this, a previously published quorum sensing reporter based on the Vibrio fischeri luxR gene and PluxI-gfp(ASV) (Andersen et al., 2001; Wu et al., 2000) was transferred to PAO-JP2. Biofilms of PAO-JP2, grown as described above, were exposed to $250 \mathrm{nM}$ OHHL [N-(3-oxo-hexanoyl)-Lhomoserine lactone] and green fluorescence developed within $1 \mathrm{~h}$. Green fluorescence decreased significantly within $2 \mathrm{~h}$ and completely disappeared after $7 \mathrm{~h}$ when 

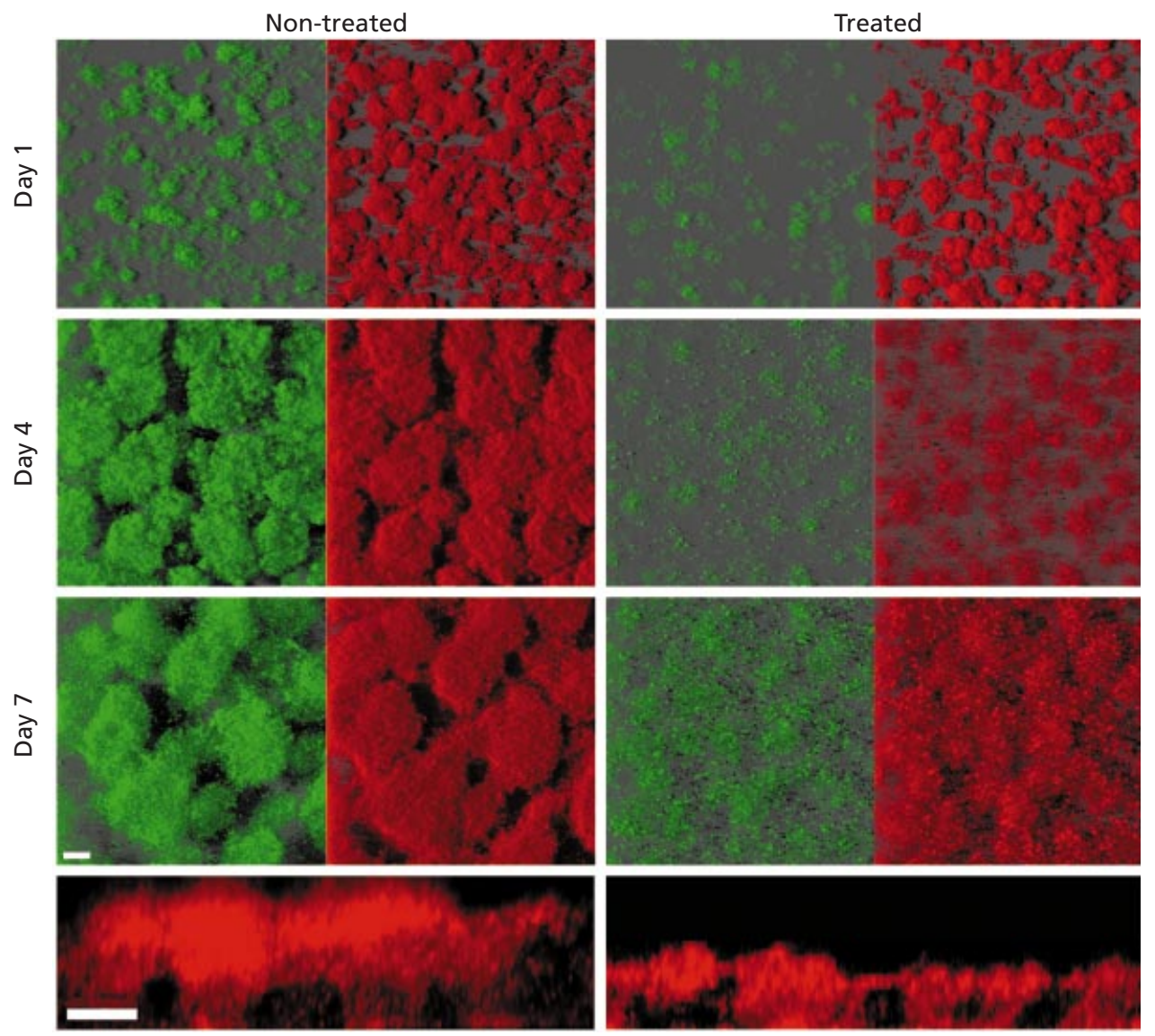

Fig. 7. Effect of furanone 56 on wild-type $P$. aeruginosa quorum sensing and biofilm formation. $P$. aeruginosa $P A O 1$ carrying the las $B$-based reporter and a dsred expression cassette on mini-Tn 5 transposons was cultivated in flow cells in the absence or presence of $5 \mu \mathrm{g}$ furanone $56 \mathrm{ml}^{-1}$. In the simulated fluorescence projections generated by SCLM, green fluorescence indicates active transcription of the QSC lasB promoter. Red fluorescence arises from constitutive expression of the $d s r e d$ gene and, therefore, correlates to bacterial biomass accumulation at the substratum. Single cells may emit both green and red fluorescence but, for clarity, the colours are shown in separate images. The lower images provide saggital views to visualize biofilm structure and thickness (day 7). Bars, $20 \mu \mathrm{m}$. The medium was ABt containing $0.3 \mathrm{mM}$ glucose.

$15 \mu \mathrm{g}$ furanone $56 \mathrm{ml}^{-1}$ was supplied in the medium flow (Fig. 8).

\section{DISCUSSION}

QSC gene expression, i.e. cell-density-dependent gene regulation, has been shown to be a common phenomenon in many Gram-negative bacteria (Fuqua \& Greenberg, 1999; Greenberg, 1997; Parsek \& Greenberg, 2000). In most known cases, quorum sensing systems control expression of virulence factors and hydrolytic enzymes (for recent reviews see Eberl, 1999; de Kievit \& Iglewski, 2000). More complex phenotypes are also known to be QSC, including swarming motility of $S$. liquefaciens which is a specialized, flagella-driven movement by which a bacterial community can, in the presence of extracellular biosurfactant, spread as a biofilm over a surface (Eberl et al., 1996, 1999; Givskov et al., 1997, 1998; Rasmussen et al., 2000). Evidence is accumulating that the ability to form surface-associated, structured and co-operative consortia (referred to as biofilms) in many organisms may involve quorum sensing regulation (Costerton et al., 1999; Davies et al., 1998; Eberl et al., 1999). P. aeruginosa has become one of the important model organisms for research in this field. This opportunistic pathogen produces a battery of extracellular virulence factors. The quorum sensing circuits of $P$. aeruginosa have been demonstrated to exert positive transcriptional control on the majority of genes encoding virulence factors, e.g. las $B$ (elastase), las A (staphylolytic protease), tox A (exotoxin A) and aprA (alkaline protease) (Brint \& Ohman, 1995; Gambello et al., 1993; Gambello \& Iglewski, 1991; Ochsner \& Reiser, 1995; Pearson et al., 1995; Seed et al., 1995; Toder et al., 1991). Recent studies estimated that $1-4 \%$ of $P$. aeruginosa genes are subject to quorum sensing control (Whiteley et al., 1999) and, thereby, support the view that quorum sensors are involved in global control of gene expression.

$P$. aeruginosa has been shown to form organized, surface-attached microbial communities, called bio- 

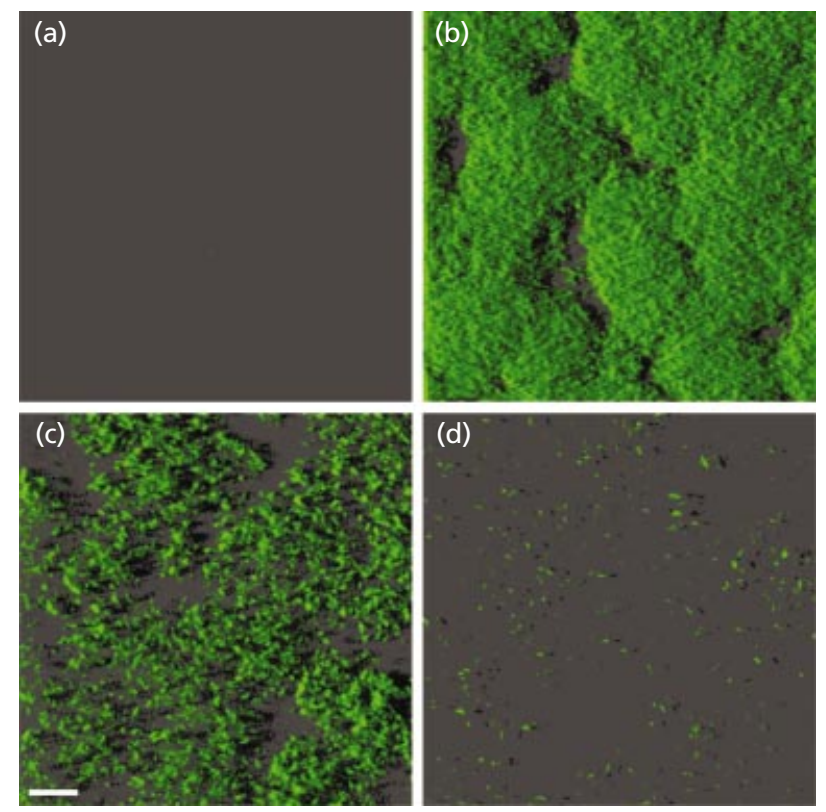

Fig. 8. Effect of furanone 56 on the $V$. fischeri lux quorum sensing system in a $P$. aeruginosa background. Plasmid pJBA132Gm carrying the luxR luxl-gfp(ASV) reporter (Andersen et al., 2001) was transferred to PAO-JP2. The resulting strain, PAO-JP2(pJBA312Gm), was grown in ABt-LB medium in flow cells and studied by SCLM. A 24-h-old, non-fluorescent biofilm (a) was exposed to $250 \mathrm{nM}$ OHHL. Within $1 \mathrm{~h}$ the biofilm bacteria became green-fluorescent (b). The medium was then further modified to contain $250 \mathrm{nM} \mathrm{OHHL}$ and $15 \mu \mathrm{g}$ furanone $56 \mathrm{ml}^{-1}$. After an additional $2 \mathrm{~h}$, biofilm bacteria were significantly less green-fluorescent (c). Six hours following the introduction of furanone 56, green fluorescence had almost completely disappeared (b). Bar, $20 \mu \mathrm{m}$.

films. This trait has been linked to pathogenicity of the organism in relation to pulmonary infections in cystic fibrosis (Hoiby \& Koch, 1990; Koch \& Hoiby, 1993; Pedersen et al., 1992). The biofilm mode of growth seems to provide the ideal scenario for AHL-mediated quorum sensing. In contrast to the planktonic mode of growth, where signal molecules are likely to become diluted in the medium and carried away by flow, biofilms offer a diffusion-limited environment which may allow the signal compounds to reach the critical threshold concentration (Charlton et al., 2000). A recent study linked quorum sensing and biofilm development by demonstrating that a lasI mutant is incapable of forming a highly structured wild-type-like biofilm (Davies et al., 1998). This observation emphasizes the need for studying quorum sensing in $P$. aeruginosa at the community level and investigating the interplay between bacterial communication, biofilm mode of growth and pathogenesis.

Clinical studies have shown that the development of resistance to antibiotics in $P$. aeruginosa is a serious sideeffect of current anti-pseudomonal treatment (Ciofu et al., 1994). This has encouraged us to engage in the development of novel non-antibiotic, anti-bacterial therapies based on QSI compounds that specifically block bacterial signalling systems. In contrast to traditional anti-microbial agents, QSI compounds work at concentrations that are well below the minimal inhibitory concentration. This concept is attractive, since such compounds will not create a selection pressure for development of resistance. Furthermore, bacteria that are insensitive to the QSI compounds because of mutations in the LuxR-type receptor proteins are expected to be unable to signal each other and therefore unable to coordinate their effort. Finally, since the selected QSIs are non-toxic for bacteria at the concentrations used, they are not expected to exhibit adverse effects on beneficial bacterial consortia present in the host (for example the gut flora).

In this study we have developed novel molecular tools which allow in situ detection of AHL-mediated quorum sensing and quorum sensing inhibition in $P$. aeruginosa biofilms. Our monitor system relies on a reporter gene fusion to a QSC promoter from P. aeruginosa. We have chosen the well characterized lasB promoter (Bever \& Iglewski, 1988; Fukushima et al., 1997; Gambello \& Iglewski, 1991; Rust et al., 1996; Toder et al., 1994) and used a translational reporter fusion that retains the $5^{\prime}$ untranslated region of the las $B$ transcript, the native RBS and spacing to the translational start. This might be important as the $5^{\prime}$ untranslated las $B$ mRNA is involved in post-transcriptional iron control of elastase expression (Brumlik \& Storey, 1992, 1998). An unstable variant of Gfp (Andersen et al., 1998, 2001) has been used as reporter. This protein is an optimal bacterial reporter for non-invasive, real-time studies of gene expression at the single-cell level because no exogenous substrates and cofactors are required, except for trace amounts of oxygen for maturation, and Gfp normally does not interfere with growth of the host (Chalfie et al., 1994). Notably, the unstable Gfp variant allows detection of transient bacterial communication.

The present quorum sensing reporter is highly sensitive, even when present as a single chromosomal copy, and detects OdDHL at concentrations as low as $20 \mathrm{nM}$ (data not shown). In agreement with the study of Passador $e t$ al. (1996), we found that OdDHL was most efficient in stimulating las $B$ promoter activity, whereas ODHL and OOHL were less efficient (Fig. 2). None of the other AHL compounds tested resulted in detectable expression of the reporter gene fusion. The concentration of OdDHL needed for half-maximal activation of the las $B$ promoter was $\approx 250 \mathrm{nM}$, i.e. about $1 / 20$ of that found in stationary-phase culture fluids of PAO1. Pearson et al. (1995) reported that $1 \mu \mathrm{M}$ OdDHL was required for half-maximal activation of a similar construct. However, our estimate is based on a reporter system in a single chromosomal copy in PAO-JP2, whereas the former study used a plasmid-based reporter (pKDT17) in a $P$. aeruginosa rhlR mutant (PAO-R1). The differences in copy number and strain background could account for the different estimates.

We have cultivated $P$. aeruginosa strains harbouring the 
quorum sensing reporter in laboratory-based flow cells. Using SCLM, we were able to monitor quorum sensing in situ at the single-cell level in biofilms. In this study we did not perform a detailed study on the induction of the reporter system in wild-type biofilms in relation to microcolony quorum size or threshold OdDHL concentration. However, we did observe that the size of the microcolonies did correlate with induction of the las $B$ reporter fusion as would be expected (Fig. 6). In PAOJP2 biofilms, lasB promoter activity could be induced by OdDHL at concentrations as low as $20 \mathrm{nM}$.

Furanone compounds produced by D. pulchra have previously been demonstrated to specifically interfere with several AHL-regulated bacterial processes without any effect on bacterial growth or general protein synthesis capability (Givskov et al., 1996; Manefield et al., 2000). The current hypothesis is that the furanone compounds antagonize AHLs by competition for the binding site on the receptor protein. Recently, Manefield et al. (1999) showed that halogenated furanones, at the concentrations produced by the alga, are capable of displacing OHHL molecules from the cognate LuxR receptor protein.

In this study we have employed a novel synthetic furanone which displays enhanced AHL-antagonistic properties and has no or little effect on growth of $P$. aeruginosa. Quantitative data from planktonic cultures showed that furanone 56 caused a significant reduction in OdDHL-activated expression of a lasB-gfp(ASV) reporter in $P$. aeruginosa. The interference by furanone 56 occurs in a competitive fashion, although the stochiometric furanone/OdDHL ratio is approximately $400: 1$. This ratio is in good agreement with the study by Kline et al. (1999) using structural analogues of OdDHL as possible agonists and antagonists of OdDHL. The disproportionate ratio probably reflects the welldocumented high affinity of LasR for OdDHL (Gray et al., 1994; Passador et al., 1996). This might also explain our failure to achieve complete inhibition of las $B$ expression by the addition of non-toxic concentrations of furanone 56. The compound repressed lasB promoter activity in a heterologous E. coli background devoid of an AHL-mediated quorum sensing system. This supports the model that the algal metabolite specifically interferes with AHL-dependent gene transcription at the level of the LasR regulatory protein.

The $P$. aeruginosa las and $r h l$ quorum sensing circuits are subject to additional levels of regulation. Transcription of lasR was shown to be positively regulated by the virulence factor regulator Vfr (Albus et al., 1997) and to be subject to negative regulation by the product of the $r s a L$ gene, recently identified downstream of las $R$ (de Kievit et al., 1999). Production of BHL was shown to be reduced in a $P$. aeruginosa gacA mutant and a model has been proposed that places GacA upstream of LasR and RhlR (Reimmann et al., 1997). Moreover, recent results suggest that the $r h l$ system is controlled by RpoS, a sigma factor required for the general stress response of P. aeruginosa (Whiteley et al., 2000). It might be speculated that the furanone interferes with one or more of these higher level regulatory circuits. To exclude this possibility, we investigated if the furanone affects a heterologous quorum sensing system hosted by $P$. aeruginosa. The Vibrio fischeri lux quorum sensing system represents a distinct cell-to-cell communication system not amenable to endogenous $P$. aeruginosa regulators and might be regarded as a 'clean' system in $P$. aeruginosa. In the present study, furanone 56 was observed to interfere with OHHL-LuxR activated expression of a luxR PluxI-gfp(ASV) fusion. This strengthens the hypothesis that the furanone antagonizes AHLs by interaction with LuxR-type receptors. Second, the effect on the luxR-PluxI-gfp(ASV) reporter indicates that furanone 56 has a broad activity in interaction with LuxR-type receptor proteins, i.e. the particular furanone is not limited only to being an antagonist of OdDHLLasR complex formation in $P$. aeruginosa, but might also be used to interfere with AHL-mediated cell-to-cell communication in other Gram-negative bacteria.

The furanone did not have any significant effect on bacterial growth rates at concentrations below $10 \mu \mathrm{g} \mathrm{ml}^{-1}$. In addition, we observed no negative, nonAHL related effects on bacterial protein synthesis when Gfp expression under the control of the araBAD promoter was induced by suboptimal levels of $\mathrm{L}-$ arabinose. The data are in agreement with previous two-dimensional PAGE analysis, demonstrating that furanones have no gross effect on bacterial protein synthesis (Manefield et al., 1999).

The lasB transcription data were complemented by measurements of the production of two QSC virulence factors, elastase and chitinase. In PAO-JP2, OdDHL, added alone or in combination with BHL, clearly stimulated protease and chitinase expression. Addition of furanone 56 reduced the activities to near the uninduced level. OdDHL and BHL synergistically induced protease activity as reported by Pearson et al. (1995). Importantly, the furanone compound was capable of repressing protease activity in the presence of OdDHL and BHL. This suggests that the furanone is also active against the $r h l$ quorum sensing system.

We have developed a novel dual-labelling methodology to study quorum sensing in wild-type $P$. aeruginosa biofilms. $P$. aeruginosa PAO1 was manipulated to contain the lasB-gfp(ASV) fusion as a green-fluorescent reporter of quorum sensing. Additionally, the strain was equipped with a chromosomally integrated Rfp expression cassette to provide a constitutive redfluorescent colour tag on biofilm bacteria. To our knowledge, this is the first report on the utilization of Rfp in P. aeruginosa. Inhibition of AHL-mediated signalling in the wild-type strain presents additional challenges: the AHL concentration cannot be controlled and the reporter system is subject to additional regulation by the $r h l$ quorum sensing system, which works in conjunction with the las circuit to maximize las $B$ expression (Pearson et al., 1995). Furthermore, the reporter system in the wild-type responds to endogenous 
and exogenous OdDHL, whereas the PAO-JP2-based reporter strain responds solely to incoming signal molecules. Considering the potential involvement of efflux pumps in transport of furanone compounds, this might be an important difference. Transcription of the las $B$ promoter was reduced approximately twofold in planktonic cultures of PAO1. In biofilms, the reporter system was partially shut down in the presence of $5 \mu \mathrm{g}$ furanone $56 \mathrm{ml}^{-1}$. It is uncertain if the relatively weak reduction of lasB expression would be sufficient to render the wild-type strain significantly less virulent. However, keeping in mind that las $B$ belongs to the top of the quorum sensing cascade (Latifi et al., 1996; Seed et al., 1995), it is likely that qsc genes located at lower levels in the regulatory hierarchy might be more severely affected as these genes require higher OdDHL concentrations for activation. The observations by Davies et al. (1998) indicate the existence of $q s c$ genes involved in late $P$. aeruginosa biofilm maturation. Our study shows that early biofilm formation, i.e. attachment to the surface, is not affected by the furanone. However, we observed that the wild-type biofilm, when grown in the presence of furanone, failed to mature and showed an architecture that strongly resembled that of the PAO1 lasI mutant observed by Davies et al. (1998). This leads to the hypothesis that the furanone may inhibit expression of the yet unidentified $q s c$ gene(s) responsible for biofilm maturation.

In the present study we have demonstrated the use of a furanone compound as a QSI compound. Furanone 56 interferes with quorum-sensing-regulated transcription of a lasB-gfp(ASV) reporter fusion and reduces extracellular elastase and chitinase activity. The furanone has no or little effect on bacterial growth and protein synthesis. In our study we have focussed on the effect the furanone exerts on the las quorum sensing system, because the las system is located at the top of the quorum sensing hierarchy and controls the activity of the rhl system. However, our data suggest that the furanone is active against the $r h l$ system. Furthermore, we have demonstrated that the furanone is capable of penetrating the $P$. aeruginosa biofilm matrix where it interferes with QSC gene expression and, as a consequence, with biofilm maturation. Our study raises a number of interesting questions. What is the involvement of the efflux pumps in QSI sensitivity? Can furanone-mediated displacement of OdDHL from LasR be demonstrated? Does the QSI compound in turn affect the biocide sensitivity of PAO1 biofilms? Can the QSI properties be optimized by altered furanone structures? What is the effect of furanones on P. aeruginosa quorum sensing and pathogenicity in a mouse lung model? Several of these questions are currently being addressed in our laboratories by means of the molecular tools presented in this report. Furanone compounds seem to hold promise as AHL-antagonists and for development of novel non-antibiotic, anti-pathogenic agents, which interfere with bacterial cell-to-cell communication and render bacteria less virulent and more sensitive to biocide treatment.

\section{ACKNOWLEDGEMENTS}

We thank Clay Fuqua, Department of Biology, Indiana University, Bloomington, for valuable advice on the $\operatorname{araC} \mathrm{P}_{\mathrm{BAD}}$ expression system. Work on quorum sensing in biofilms and signal inhibitors was supported by grants from the Danish Medical Research Council (SSVF), the Danish Technical Research Council (STVF), the Villum-Kann Rasmussen Foundation, the Danish Plasmid Foundation, the Australian Research Council and the Centre for Marine Biofouling and Bio-Innovation.

\section{REFERENCES}

Albus, A. M., Pesci, E. C., Runyen-Janecky, L. J., West, S. E. \& Iglewski, B. H. (1997). Vfr controls quorum sensing in Pseudomonas aeruginosa. J Bacteriol 179, 3928-3935.

Andersen, J. B., Sternberg, C., Poulsen, L. K., Bjorn, S. P., Givskov, M. \& Molin, S. (1998). New unstable variants of green fluorescent protein for studies of transient gene expression in bacteria. Appl Environ Microbiol 64, 2240-2246.

Andersen, J. B., Heydorn, A., Hentzer, M., Eberl, L., Geisenberger, O., Christensen, B. B., Molin, S. \& Givskov, M. (2001). gfp based $\mathrm{N}$-acyl-homoserine-lactone monitors for detection of bacterial communication. Appl Environ Microbiol 67, 575-585.

Anderson, R. M., Zimprich, C. A. \& Rust, L. (1999). A second operator is involved in Pseudomonas aeruginosa elastase (lasB) activation. J Bacteriol 181, 6264-6270.

Ayora, S. \& Götz, F. (1994). Genetic and biochemical properties of an extracellular neutral metalloprotease from Staphylococcus byicus subsp. hyicus. Mol Gen Genet 242, 421-430.

Bertani, G. (1951). Studies on lysogenesis. I. The mode of phage liberation by lysogenic Escherichia coli. J Bacteriol 62, 293-300.

Bever, R. A. \& Iglewski, B. H. (1988). Molecular characterization and nucleotide sequence of the Pseudomonas aeruginosa elastase structural gene. J Bacteriol 170, 4309-4314.

Bloemberg, G. V., O’Toole, G. A., Lugtenberg, B. J. J. \& Kolter, R. (1997). Green fluorescent protein as a marker for Pseudomonas spp. Appl Environ Microbiol 63, 4543-4551.

von Bodman, S. B. \& Farrand, S. K. (1995). Capsular polysaccharide biosynthesis and pathogenicity in Erwinia stewartii require induction by an $\mathrm{N}$-acylhomoserine lactone autoinducer. $J$ Bacteriol 177, 5000-5008.

Brint, J. M. \& Ohman, D. E. (1995). Synthesis of multiple exoproducts in Pseudomonas aeruginosa is under the control of RhlR-RhlI, another set of regulators in strain PAO1 with homology to the autoinducer-responsive LuxR-LuxI family. $J$ Bacteriol 177, 7155-7163.

Brumlik, M. J. \& Storey, D. G. (1992). Zinc and iron regulate translation of the gene encoding Pseudomonas aeruginosa elastase. Mol Microbiol 6, 337-344.

Brumlik, M. J. \& Storey, D. G. (1998). Post-transcriptional control of Pseudomonas aeruginosa las $B$ expression involves the $5^{\prime}$ untranslated region of the mRNA. FEMS Microbiol Lett 159, 233-239.

Chalfie, M., Tu, Y., Euskirchen, G., Ward, W. W. \& Prasher, D. C. (1994). Green fluorescent protein as a marker for gene expression. Science 263, 802-805.

Charlton, T. S., de Nys, R., Netting, A., Kumar, N., Hentzer, M., Givskov, M. \& Kjelleberg, S. (2000). A novel and sensitive method for the quantification of $\mathrm{N}$-3-oxo-acyl homoserine lactones using gas chromatography-mass spectrometry: application to a model bacterial biofilm. Environ Microbiol 2, 530-541. 
Christensen, B. B., Sternberg, C., Andersen, J. B., Palmer, R. J., Jr, Nielsen, A. T., Givskov, M. \& Molin, S. (1999). Molecular tools for study of biofilm physiology. Methods Enzymol 310, 20-42.

Ciofu, O., Giwercman, B., Pedersen, S. S. \& Hoiby, N. (1994). Development of antibiotic resistance in Pseudomonas aeruginosa during two decades of antipseudomonal treatment at the Danish CF Center. APMIS 102, 674-680.

Clark, D. J. \& Maaløe, O. (1967). DNA replication and the division cycle in Escherichia coli. J Mol Biol 23, 99-112.

Costerton, J. W., Lewandowski, Z., Caldwell, D. E., Korber, D. R. \& Lappin-Scott, H. M. (1995). Microbial biofilms. Annu Rev Microbiol 49, 711-745.

Costerton, J. W., Stewart, P. S. \& Greenberg, E. P. (1999). Bacterial biofilms: a common cause of persistent infections. Science 284, 1318-1322.

Davies, D. G., Parsek, M. R., Pearson, J. P., Iglewski, B. H., Costerton, J. W. \& Greenberg, E. P. (1998). The involvement of cell-to-cell signals in the development of a bacterial biofilm. Science 280, 295-298.

Diver, J. M., Bryan, L. E. \& Sokol, P. A. (1990). Transformation of Pseudomonas aeruginosa by electroporation. Anal Biochem 189, 75-79.

Eberl, L. (1999). $N$-acyl homoserinelactone-mediated gene regulation in gram-negative bacteria. Syst Appl Microbiol 22, 493-506.

Eberl, L., Winson, M. K., Sternberg, C. \& 7 other authors (1996). Involvement of $\mathrm{N}$-acyl-L-homoserine lactone autoinducers in controlling the multicellular behaviour of Serratia liquefaciens. Mol Microbiol 20, 127-136.

Eberl, L., Molin, S. \& Givskov, M. (1999). Surface motility of Serratia liquefaciens MG1. J Bacteriol 181, 1703-1712.

Fukushima, J., Ishiwata, T., You, Z. \& 9 other authors (1997). Dissection of the promoter/operator region and evaluation of $\mathrm{N}$ acylhomoserine lactone mediated transcriptional regulation of elastase expression in Pseudomonas aeruginosa. FEMS Microbiol Lett 146, 311-318.

Fuqua, C. \& Greenberg, E. P. (1999). Self perception in bacteria: quorum sensing with acylated homoserine lactones. Curr Opin Microbiol 1, 183-189.

Fuqua, C., Winans, S. C. \& Greenberg, E. P. (1997). Quorum sensing in bacteria: the LuxR-LuxI family of cell densityresponsive transcriptional regulators. J Bacteriol 176, 269-275.

Gambello, M. J. \& Iglewski, B. H. (1991). Cloning and characterization of the Pseudomonas aeruginosa lasR gene, a transcriptional activator of elastase expression. J Bacteriol 173, 3000-3009.

Gambello, M. J., Kaye, S. \& Iglewski, B. H. (1993). LasR of Pseudomonas aeruginosa is a transcriptional activator of the alkaline protease gene $(a p r)$ and an enhancer of exotoxin A expression. Infect Immun 61, 1180-1184.

Givskov, M., de Nys, R., Manefield, M., Gram, L., Maximilien, R., Eberl, L., Molin, S., Steinberg, P. D. \& Kjelleberg, S. (1996). Eukaryotic interference with homoserine lactone-mediated prokaryotic signalling. J Bacteriol 178, 6618-6622.

Givskov, M., Eberl, L. \& Molin, S. (1997). Control of exoenzyme production, motility and cell differentiation in Serratia liquefaciens. FEMS Microbiol Lett 148, 115-122.

Givskov, M., Ostling, J., Eberl, L., Lindum, P. W., Christensen, A. B., Christiansen, G., Molin, S. \& Kjelleberg, S. (1998). Two separate regulatory systems participate in control of swarming motility of Serratia liquefaciens MG1. J Bacteriol 180, 742-745.

Glessner, A., Smith, R. S., Iglewski, B. H. \& Robinson, J. B. (1999). Roles of Pseudomonas aeruginosa las and rhl quorum-sensing systems in control of twitching motility. J Bacteriol 181, $1623-1629$.

Gray, K. M., Passador, L., Iglewski, B. H. \& Greenberg, E. P. (1994). Interchangeability and specificity of components from the quorum-sensing regulatory systems of Vibrio fischeri and Pseudomonas aeruginosa. J Bacteriol 176, 3076-3080.

Greenberg, E. P. (1997). Quorum sensing in gram-negative bacteria. ASM News 63, 371-377.

Guzman, L. M., Belin, D., Carson, M. J. \& Beckwith, J. (1995). Tight regulation, modulation, and high-level expression by vectors containing the arabinose $\mathrm{P}_{\mathrm{BAD}}$ promoter. J Bacteriol 177, 4121-4130.

Hassett, D. J., Ma, J. F., Elkins, J. G. \& 10 other authors (1999). Quorum sensing in Pseudomonas aeruginosa controls expression of catalase and superoxide dismutase genes and mediates biofilm susceptibility to hydrogen peroxide. Mol Microbiol 34, 10821093.

Herrero, M., de Lorenzo, V. \& Timmis, K. N. (1990). Transposon vectors containing non-antibiotic resistance selection markers for cloning and stable chromosomal insertion of foreign genes in gram-negative bacteria. J Bacteriol 172, 6557-6567.

Hoiby, N. (1977). Pseudomonas aeruginosa infection in cystic fibrosis. Diagnostic and prognostic significance of Pseudomonas aeruginosa precipitins determined by means of crossed immunoelectrophoresis. A survey. Acta Pathol Microbiol Scand Suppl $1-96$.

Hoiby, N. (2000). Prospects for the prevention and control of pseudomonal infection in children with cystic fibrosis. Paediatr Drugs 2, 451-463.

Hoiby, N. \& Koch, C. (1990). Pseudomonas aeruginosa infection in cystic fibrosis and its management. Thorax 45, 881-884.

Holloway, B. W. (1955). Genetic recombination in Pseudomonas aeruginosa. J Gen Microbiol 13, 572-581.

Kessler, B., de Lorenzo, V. \& Timmis, K. N. (1992). A general system to integrate lac $Z$ fusions into the chromosomes of gramnegative eubacteria: regulation of the $\mathrm{Pm}$ promoter of the TOL plasmid studied with all controlling elements in monocopy. Mol Gen Genet 233, 293-301.

de Kievit, T. R. \& Iglewski, B. H. (2000). Bacterial quorum sensing in pathogenic relationships. Infect Immun 68, 4839-4849.

de Kievit, T., Seed, P. C., Nezezon, J., Passador, L. \& Iglewski, B. H. (1999). RsaL, a novel repressor of virulence gene expression in Pseudomonas aeruginosa. J Bacteriol 181, 2175-2184.

Kjelleberg, S., Steinberg, P. D., Givskov, M., Gram, L., Manefield, M. \& de Nys, R. (1999). Do marine natural products interfere with prokaryotic AHL regulatory systems? Aquat Microb Ecol 13, 85-93.

Kleerebezem, M., Quadri, L. E., Kuipers, O. P. \& de Vos, W. M. (1997). Quorum sensing by peptide pheromones and twocomponent signal-transduction systems in Gram-positive bacteria. Mol Microbiol 24, 895-904.

Kline, T., Bowman, J., Iglewski, B. H., de Kievit, T., Kakai, Y. \& Passador, L. (1999). Novel synthetic analogs of the Pseudomonas autoinducer. Bioorg Med Chem Lett 9, 3447-3452.

Koch, C. \& Hoiby, N. (1993). Pathogenesis of cystic fibrosis. Lancet 341, 1065-1069.

Lam, J., Chan, R., Lam, K. \& Costerton, J. W. (1980). Production of mucoid microcolonies by Pseudomonas aeruginosa within infected lungs in cystic fibrosis. Infect Immun 28, 546-556.

Latifi, A., Foglino, M., Tanaka, K., Williams, P. \& Lazdunski, A. (1996). A hierarchical quorum-sensing cascade in Pseudomonas 
aeruginosa links the transcriptional activators LasR and RhIR (VsmR) to expression of the stationary-phase sigma factor RpoS. Mol Microbiol 21, 1137-1146.

Lindum, P. W., Anthoni, U., Christophersen, C., Eberl, L., Molin, S. \& Givskov, M. (1998). N-Acyl-L-homoserine lactone autoinducers control production of an extracellular lipopeptide biosurfactant required for swarming motility of Serratia liquefaciens MG1. J Bacteriol 180, 6384-6388.

de Lorenzo, V., Herrero, M., Jakubzik, U. \& Timmis, K. N. (1990). Mini-Tn5 transposon derivatives for insertion mutagenesis, promoter probing, and chromosomal insertion of cloned DNA in gram-negative eubacteria. J Bacteriol 172, 6568-6572.

Manefield, M., de Nys, R., Kumar, N., Read, R., Givskov, M., Steinberg, P. D. \& Kjelleberg, S. (1999). Evidence that halogenated furanones from Delisea pulchra inhibit acylated homoserine lactone (AHL)-mediated gene expression by displacing the AHL signal from its receptor protein. Microbiology 145, 283-291.

Manefield, M., Harris, L., Rice, S. A., de Nys, R. \& Kjelleberg, S. (2000). Inhibition of luminescence and virulence in the black tiger prawn (Penaeus monodon) pathogen Vibrio harveyi by intercellular signal antagonists. Appl Environ Microbiol 66, 20792084.

Manny, A. J., Kjelleberg, S., Kumar, N., de Nys, R., Read, R. \& Steinberg, P. (1997). Reinvestigation of the sulfuric acid-catalysed cyclisation of brominated 2-alkyllevulinic acids to 3-alkyl-5methylene-2(5h)-furanones. Tetrahedron 53, 15813-15826.

de Nys, R., Wright, A. D., König, G. M. \& Sticher, O. (1993). New halogenated furanones from the marine alga Delisea pulchra. Tetrahedron 49, 11213-11220.

de Nys, R., Steinberg, P. D., Willemsen, P., Dworjanyn, S. A., Gabelish, C. L. \& King, R. J. (1995). Broad spectrum effects of secondary metabolites from the red alga Delisea pulchra in antifouling assays. Biofouling 8, 259-271.

Ochsner, U. A. \& Reiser, J. (1995). Autoinducer-mediated regulation of rhamnolipid biosurfactant synthesis in Pseudomonas aeruginosa. Proc Natl Acad Sci US A 92, 6424-6428.

O’Toole, G. A. \& Kolter, R. (1998). Flagellar and twitching motility are necessary for Pseudomonas aeruginosa biofilm development. Mol Microbiol 30, 295-304.

Parsek, M. R. \& Greenberg, E. P. (2000). Acyl-homoserine lactone quorum sensing in gram-negative bacteria : a signaling mechanism involved in associations with higher organisms. Proc Natl Acad Sci US A 97, 8789-8793.

Passador, L. \& Iglewski, B. H. (1995). Quorum sensing and virulence gene regulation in Pseudomonas aeruginosa. In Virulence Mechanisms of Bacterial Pathogens, pp. 65-78. Edited by J. A. Roth. Washington, DC: American Society for Microbiology.

Passador, L., Cook, J. M., Gambello, M. J., Rust, L. \& Iglewski, B. H. (1993). Expression of Pseudomonas aeruginosa virulence genes requires cell-to-cell communication. Science 260, 1127-1130.

Passador, L., Tucker, K. D., Guertin, K. R., Journet, M. P., Kende, A. S. \& Iglewski, B. H. (1996). Functional analysis of the Pseudomonas aeruginosa autoinducer PAI. J Bacteriol 178, 5995-6000.

Pearson, J. P., Gray, K. M., Passador, L., Tucker, K. D., Eberhard, A., Iglewski, B. H. \& Greenberg, E. P. (1994). Structure of the autoinducer required for expression of Pseudomonas aeruginosa virulence genes. Proc Natl Acad Sci U S A 91, 197-201.

Pearson, J. P., Passador, L., Iglewski, B. H. \& Greenberg, E. P. (1995). A second $\mathrm{N}$-acylhomoserine lactone signal produced by Pseudomonas aeruginosa. Proc Natl Acad Sci USA 92, 1490-1494.

Pearson, J. P., Pesci, E. C. \& Iglewski, B. H. (1997). Roles of Pseudomonas aeruginosa las and $r h l$ quorum-sensing systems in control of elastase and rhamnolipid biosynthesis genes. J Bacteriol 179, 5756-5767.

Pedersen, S. S., Hoiby, N., Espersen, F. \& Koch, C. (1992). Role of alginate in infection with mucoid Pseudomonas aeruginosa in cystic fibrosis. Thorax 47, 6-13.

Pesci, E. C. \& Iglewski, B. H. (1997). The chain of command in Pseudomonas quorum sensing. Trends Microbiol 5, 132-134.

Pesci, E. C., Milbank, J. B., Pearson, J. P., McKnight, S., Kende, A. S., Greenberg, E. P. \& Iglewski, B. H. (1999). Quinolone signaling in the cell-to-cell communication system of Pseudomonas aeruginosa. Proc Natl Acad Sci US A 96, 11229-11234.

Piper, K. R., von Bodman, S. B. \& Farrand, S. K. (1993). Conjugation factor of Agrobacterium tumefaciens regulates $\mathrm{Ti}$ plasmid transfer by autoinduction. Nature 362, 448-450.

Pollack, M. (1990). Pseudomonas aeruginosa. In Principles and Practice of Infectious Diseases, pp. 1673-1691. Edited by G. L. Mandell, R. G. Douglas \& J. E. Bennett. New York: Churchhill Livingstone.

Rasmussen, T. B., Manefield, M., Andersen, J. B., Eberl, L., Anthoni, U., Christophersen, C., Steinberg, P., Kjelleberg, S. \& Givskov, M. (2000). How Delisea pulchra furanones affect quorum sensing and swarming motility in Serratia liquefaciens MG1. Microbiology 146, 3237-3244.

Reichelt, J. L. \& Borowitzka, M. A. (1984). Antimicrobial activity from marine algae: results of a large-scale screening programme. Hydrobiology 116/117, 158-168.

Reimmann, C., Beyeler, M., Latifi, A., Winteler, H., Foglino, M., Lazdunski, A. \& Haas, D. (1997). The global activator GacA of Pseudomonas aeruginosa $\mathrm{PAO}$ positively controls the production of the autoinducer N-butyryl-homoserine lactone and the formation of the virulence factors pyocyanin, cyanide, and lipase. Mol Microbiol 24, 309-319.

Rust, L., Pesci, E. C. \& Iglewski, B. H. (1996). Analysis of the Pseudomonas aeruginosa elastase (lasB) regulatory region. J Bacteriol 178, 1134-1140.

Sambrook, J., Fritsch, E. F. \& Maniatis, T. (1989). Molecular Cloning: a Laboratory Manual, 2nd edn. Cold Spring Harbor, NY: Cold Spring Harbor Laboratory.

Schlictman, D., Kubo, M., Shankar, S. \& Chakrabarty, A. M. (1995). Regulation of nucleoside diphosphate kinase and secretable virulence factors in Pseudomonas aeruginosa: roles of algR2 and algH. J Bacteriol 177, 2469-2474.

Schweizer, H. P. (1991). Improved broad-host-range lac-based plasmid vectors for the isolation and characterization of protein fusions in Pseudomonas aeruginosa. Gene 103, 87-92.

Seed, P. C., Passador, L. \& Iglewski, B. H. (1995). Activation of the Pseudomonas aeruginosa lasI gene by LasR and the Pseudomonas autoinducer PAI: an autoinduction regulatory hierarchy. $J$ Bacteriol 177, 654-659.

Singh, P. K., Schaefer, A. L., Parsek, M. R., Moninger, T. O., Welsh, M. J. \& Greenberg, E. P. (2000). Quorum-sensing signals indicate that cystic fibrosis lungs are infected with bacterial biofilms. Nature 407, 762-764.

Swift, S., Throup, J. P., Williams, P., Salmond, G. P. \& Stewart, G. S. (1996). Quorum sensing: a population-density component in the determination of bacterial phenotype. Trends Biochem Sci 21, 214-219. 
Toder, D. S., Gambello, M. J. \& Iglewski, B. H. (1991). Pseudomonas aeruginosa LasA: a second elastase under the transcriptional control of lasR. Mol Microbiol 5, 2003-2010.

Toder, D. S., Ferrell, S. J., Nezezon, J. L., Rust, L. \& Iglewski, B. H. (1994). las $A$ and las $B$ genes of Pseudomonas aeruginosa: analysis of transcription and gene product activity. Infect Immun 62, 1320-1327.

Van Delden, C. \& Iglewski, B. H. (1998). Cell-to-cell signaling and Pseudomonas aeruginosa infections. Emerg Infect Dis 4, 551-560.

West, S. E. H., Schweizer, H. P., Dall, C., Sample, A. K. \& Runyenjanecky, L. J. (1994). Construction of improved Escherichia-Pseudomonas shuttle vectors derived from pUC18/19 and sequence of the region required for their replication in Pseudomonas aeruginosa. Gene 148, 81-86.

Whiteley, M., Lee, K. M. \& Greenberg, E. P. (1999). Identification of genes controlled by quorum sensing in Pseudomonas aeruginosa. Proc Natl Acad Sci U S A 96, 13904-13909.
Whiteley, M., Parsek, M. R. \& Greenberg, E. P. (2000). Regulation of quorum sensing by RpoS in Pseudomonas aeruginosa. J Bacteriol 182, 4356-4360.

Williams, P., Camara, M., Hardman, A. \& 7 other authors (2000). Quorum sensing and the population-dependent control of virulence. Philos Trans R Soc Lond B Biol Sci 355, 667-680.

Winson, M. K., Camara, M., Latifi, A. \& 10 other authors (1995). Multiple $\mathrm{N}$-acyl-L-homoserine lactone signal molecules regulate production of virulence determinants and secondary metabolites in Pseudomonas aeruginosa. Proc Natl Acad Sci USA 92, 9427-9431.

Wu, H., Song, Z., Hentzer, M. \& 8 other authors (2000). Detection of $\mathrm{N}$-acylhomoserine lactones in lung tissues of mice infected with Pseudomonas aeruginosa. Microbiology 146, 2481-2493.

Received 15 March 2001; revised 31 August 2001; accepted 12 September 2001. 